IZA DP No. 8671

Terrorism and Human Capital at Birth: Bomb Casualties and Birth Outcomes in Spain

Climent Quintana-Domeque Pedro Ródenas-Serrano

November 2014 


\title{
Terrorism and Human Capital at Birth: Bomb Casualties and Birth Outcomes in Spain
}

\author{
Climent Quintana-Domeque \\ University of Oxford \\ and IZA
}

Pedro Ródenas-Serrano

Universitat d'Alacant

\section{Discussion Paper No. 8671 \\ November 2014}

\author{
IZA \\ P.O. Box 7240 \\ 53072 Bonn \\ Germany \\ Phone: +49-228-3894-0 \\ Fax: +49-228-3894-180 \\ E-mail: iza@iza.org
}

\begin{abstract}
Any opinions expressed here are those of the author(s) and not those of IZA. Research published in this series may include views on policy, but the institute itself takes no institutional policy positions. The IZA research network is committed to the IZA Guiding Principles of Research Integrity.

The Institute for the Study of Labor (IZA) in Bonn is a local and virtual international research center and a place of communication between science, politics and business. IZA is an independent nonprofit organization supported by Deutsche Post Foundation. The center is associated with the University of Bonn and offers a stimulating research environment through its international network, workshops and conferences, data service, project support, research visits and doctoral program. IZA engages in (i) original and internationally competitive research in all fields of labor economics, (ii) development of policy concepts, and (iii) dissemination of research results and concepts to the interested public.
\end{abstract}

IZA Discussion Papers often represent preliminary work and are circulated to encourage discussion. Citation of such a paper should account for its provisional character. A revised version may be available directly from the author. 


\title{
ABSTRACT \\ Terrorism and Human Capital at Birth: Bomb Casualties and Birth Outcomes in Spain
}

\begin{abstract}
We study the effects of terrorism in Spain on birth outcomes, focusing on terrorism perpetrated by ETA, combining information on the number of bomb casualties from The Victims of ETA Dataset with the individual birth records from the national registry of live births in Spain, elaborated by the Spanish Statistical Institute (INE). We focus on live births conceived between January 1980 and February 2003 and find that in utero exposure to terrorism early in pregnancy, as measured by the number of bomb casualties in the mother's province of residence in the first trimester of pregnancy, has detrimental effects on birth outcomes: in terms of average birth weight (lower), prevalence of low birth weight (higher) and fraction of "normal" babies (lower). Our results are robust to a battery of checks, such as controlling for "economic" factors and accounting for spatial "spillover" effects. In addition, we investigate potential non-linear effects and explore heterogeneous effects across groups of regions, different time periods and family characteristics. In support of our identification strategy, the number of bomb casualties after birth does not predict birth outcomes. We do not find evidence of migration effects (in terms of population size responses to last year terrorist activity), but the number of still births increases with bomb casualties in the first and third trimesters of pregnancy. The estimated effect of 1 bomb casualty in the first trimester of pregnancy on average birth weight (around half a gram) is likely to be downward biased due to selective mortality. Finally, we provide a conceptual framework to understand what can be identified about the production of child health by exploiting shocks that affect (unobserved) maternal inputs.
\end{abstract}

JEL Classification: $\quad 112, \mathrm{~J} 13$

Keywords: $\quad$ terrorism, birth weight, stress, production of child health, Spain

Corresponding author:

Climent Quintana-Domeque

University of Oxford

Department of Economics

Manor Road Building

Manor Road

Oxford OX1 3UQ

United Kingdom

E-mail: climent.quintana-domeque@economics.ox.ac.uk

\footnotetext{
* We thank Anna Aizer, Sonia Bhalotra, Damian Clark, Ian Crawford, Paul Devereux, Martin Foureaux, Libertad González, Petter Lundborg, Dan-Olof Rooth, Sonia Oreffice, Christine Valente and seminar participants at Lund University, University of Bristol, University of Gothenburg, University of Lancaster, University of Oxford, University of Sussex and University of Toronto seminars, as well as participants at the "Effects of Early Interventions on Child Health and Education" Conference (University of Surrey), "Children's Health, Well-Being, and Human Capital" Workshop (Barcelona Graduate School of Economics), and Journées d'Economie Publique Louis-André Gérard-Varet (Aix en Provence) for comments and suggestions. The usual disclaimers apply.
} 


\section{Introduction}

Terrorism -violence committed to intimidate a population or coerce government or international organizations in the name of a political, religious or ideological purpose (Saul, 2012) - is one of today's most important challenges faced by governments (and societies) around the world. Terrorism may involve different types of direct destruction: of human capital (by killing people), of physical capital (by destroying infrastructure), or both at the same time, and economists have been studying both its consequences and its causes for several years (e.g., Krueger, 2007).

Apart from its well-known direct consequences, terrorism may also have indirect negative effects. In particular, terrorist attacks generate a disproportionate amount of stress and fear (Becker and Rubinstein, 2011). Indeed, terrorism involves stress and anxiety responses (Nijdam et al., 2010). For instance, in the months following the London attacks of July 7 2005, citizens of London experienced a significant drop in their self-reported mental health (Dustmann and Fasani, 2014).

The fact that terrorism has such indirect effects, in terms of stress, anxiety or selfreported mental health, it is not only a concern for the current generation but opens the possibility that terrorism may have negative consequences on the initial stock of human capital of an economy, and its future generations. If we think of endowments at birth, such as birth weight, as proxies for the initial stock of human capital of an economy, we may well be worried that terrorism is damaging such stock by exerting a negative effect on its development during the critical stages of gestation (Almond and Currie, 2011, Heckman, 2007).

There is evidence suggesting that terrorist shocks negatively affect birth outcomes (e.g., Brown, 2012; Currie and Schwandt, 2014), which may appear consistent with research showing that women who experience stress in the early stages of pregnancy are at increased risk of having a low birth weight child (e.g., Beydoun and Saftlas, 2008). ${ }^{1}$

\footnotetext{
${ }^{1}$ Stress during pregnancy could have negative effects on the fetus through neuroendocrine changes,
} 
We analyze the effects of bomb casualties caused by ETA terrorism on birth outcomes in Spain. ${ }^{2}$ We investigate a sequence of terrorist shocks, those happening between January 1980 and February 2003, with negligible effects on resources and pollution (at least compared to other types of terrorist attacks such as September 11). In other words, any effect of terrorism on birth outcomes is expected to come through an increase in fear and stress. We combine information on the number of bomb casualties from The Victims of ETA Dataset (2007), elaborated by de la Calle and Sánchez-Cuenca, with the individual birth records from the national registry of live births in Spain, elaborated by the Spanish Statistical Institute (INE).

We focus on live births conceived between January 1980 and February 2003, a period characterized by attrition attacks ${ }^{3}$, and investigate the impact of bomb casualties in each trimester of pregnancy on a battery of birth outcomes: birth weight (in grams), low birth weight (1 if birth weight less than 2,500 grams), prematurity ( $<37$ weeks), "normality" (absence of complications during the pregnancy or labor) and gender of the child.

The choice of these outcomes is not random. It is dictated in part by what we know from existing research, and in part because of data limitations. Birth weight, low birth-weight and prematurity are standard birth outcomes. In particular, low birth-weight is a predictor of both child health (e.g., McCormick, 1985; Pollack and Divon, 1992) and long-term outcomes such as educational attainment, labor market outcomes, and adult health (e.g., Behrman and Rosenzweig, 2004; Black, Devereux and Salvanes, 2007). However, as pointed out recently by Currie and Rossin-Slater (2013), measured effects of stressful events on birth

changes in immune function, and/or through behavioral channels (Dunkel-Schetter, 2011).

${ }^{2}$ ETA (Euskadi ta Askatasuna or Basque Homeland and Freedom) was a terrorist organization who sought to gain independence for a Basque homeland in northern Spain and southern France. ETA announced "the definitive cessation of its armed activity" in October 2011. While no attack has been perpetrated by ETA since then, the Barómetro del CIS (2013) opinion polls show that ETA terrorism has been one of the main worries of Spaniards during the last 30 years.

${ }^{3}$ Attacks that took take place in more distant locations than the territory the terrorist group hopes to eventually govern and are aimed at exhausting the government economically, politically, and ultimately psychologically into agreeing to group demands (de la Calle and Sánchez-Cuenca, 2006; LaFree et al., 2012). Prior to 1980 the registry of live births does not provide information on birth weight. The upper limit avoids Madrid train bombings (March 11 2004) interfering with our estimates. 
weight, low birth-weight and prematurity may be sensitive to the econometric specification, and it is preferable to use sensitive indicators of newborn health, such as the probability of abnormal conditions of the newborn (here we use "normality"). Finally, and following Brown (2012), we also consider gender as a potential outcome of exposure to terrorism while in utero, since maternal stress may impact the sex ratio by reducing male births (Catalano et al., 2006).

Our identification is based on a difference-in-difference strategy across provinces (50 geographical regions) and time (more than 275 conception month-years). We regress birth outcomes on the number of bomb casualties in each trimester of pregnancy controlling for province and conception month-years. In addition, our most complete econometric specification include several socio-demographic and maternal controls (mother's age, order of birth, mother's marital status, mother's occupation, father's occupation, municipality size, place of birth) and province-specific linear (month-by-year) time trends.

While we do not have measures of maternal behavior (or maternal health), such as smoking or drinking habits, the last part of the paper provides a conceptual framework to understand what can be identified about the production of child health by exploiting shocks that affect these maternal inputs, such as bomb casualties or unemployment fluctuations. We test the implication of this conceptual framework.

We find that in utero exposure to terrorism early in pregnancy (1st trimester), as measured by the number of bomb casualties, has detrimental effects on birth outcomes: in terms of average birth weight (lower), the prevalence of low birth weight (higher) and the fraction of normal babies (lower). Our results are robust to the presence of spatial "spillover" effects (as measured by the number of bomb casualties in each trimester of pregnancy in provinces "close" to the mother's province of residence) and to controlling for economic conditions in each trimester of pregnancy (as measured by unemployment rates).

In support of our identification strategy, we present two falsification tests. The first shows that the number of bomb casualties after birth does not predict birth outcomes. The 
second indicates that when bomb casualties at the province-quarterly level are randomly allocated, we cannot reject that exposure to terrorism in the 1st trimester of pregnancy has a null effect on birth outcomes. We also explore heterogeneous effects, by region, period and family characteristics. There is evidence that the effects are driven by trimesters with "high intense terrorism" (say 10 bomb casualties or more), rather than by trimesters with "some terrorism" (say one bomb casualty or more).

We also investigate migration patterns, fertility responses and the effects of terrorism on still births. We do not find evidence of migration responses (in terms of population size responses) to last year terrorist activity. However, terrorist activity during the trimester before the 1st trimester of pregnancy (conception period) increases the number of live births, and the number of still births increases with bomb casualties in the first and third trimesters of pregnancy. Given the increase in the number of still births, the estimated effect of one bomb casualty in the first trimester of pregnancy on average birth weight for live births -which is equivalent to the effect of a decrease in economic activity of 0.15 percentage points in Argentina (Bozzoli and Quintana-Domeque, 2014)- is likely to be downward biased due to selective mortality. While we do not observe maternal inputs (smoking behavior, drinking behavior, antenatal visits) in our data, in the last part of the paper we provide a conceptual framework to understand what can be identified about the production of child health by exploiting shocks that affect these maternal inputs. We show how we can identify the "marginal rate of technical transformation" in the production of child health between terrorist shocks and unemployment rates, acknowledging that this captures a mixture of both biological and behavioral responses.

Studying the effects of September 11 terrorist attacks on birth outcomes, Brown (2012) finds that children exposed while in utero to these attacks were born significantly smaller and earlier than previous cohorts. While his findings are consistent with terrorism increasing maternal stress -i.e., maternal stress increasing the probability of low birth weight babies and of prematurity- it is important to acknowledge that September 11 was not only a source 
of acute maternal stress but also had negative pollution and resource shocks (Bram, Orr and Rapaport, 2002; Landrigan, 2001), which are known to have negative consequences on child health. Indeed, Currie and Schwandt (2014), describe the events of 9/11 as an unparalleled environmental disaster, releasing a million tons of toxic dust into lower Manhattan. Hence, it is difficult to think of maternal stress as the unique (or even main) driving force of birth outcomes behind the September 11 terrorist attacks. ${ }^{4}$ In Spain, ETA terrorist attacks have had negligible effects (if any) on resources and pollution.

Another issue when studying the September 11 terrorist attacks is the fact that September 11 was just one shock event happening in a particular moment in time. When thinking of the effects of terrorism, we would like to have a sense of the consequences of (unexpected) terrorist shocks happening over a period of time: In Spain, the number of bomb casualties in a province one month before, nine months before or 1 year before does not predict bomb casualties in that same province. ${ }^{5}$

Perhaps, the most comparable study to ours, in that they try to estimate the impact of number of casualties per trimester of pregnancy on birth outcomes, is the one by Mansour and Rees (2012). These authors provide the first study on the effect of intrauterine exposure to armed conflict on pregnancy outcomes with evidence from the al-Aqsa Intifada. ${ }^{6}$ Using data from the Palestinian Demographic Health Survey 2004, they find that an additional conflict-related fatality 9-6 months before birth is associated with a modest increase in the probability of having a child who weighed less than 2,500 grams.

While methodologically similar, the study by Mansour and Rees (2012) suffers from certain limitations that we can overcome. First, their sample size is very small (hundreds or thousands), while here we use administrative records (millions), so we have enough statistical power. Second, different from us, they do not observe gestational length, so that they

\footnotetext{
${ }^{4}$ While Brown excludes residents of the attacked areas to remove the influences of pollution and resource shocks, part of the relevant effect of stress on birth outcomes is missed by using this approach.

${ }^{5}$ The coefficients for these three regressions are 0.006, 0.011 and 0.002 , respectively, and its corresponding R-squared's 0.00. Results available upon request.

${ }^{6}$ The name commonly used to describe a series of violent clashes between the Palestinians and Israel in the time frame between 2000 and 2004.
} 
measure exposure by counting backwards from the date of birth, which means that exposure in the first trimester is likely going to be assigned with measurement error for pre-term babies (Currie and Rossin-Slater, 2013). Third, while the al-Aqsa Intifada inflicted intense psychological damage on noncombatants living in the West Bank and Gaza, Mansour and Rees recognize that other channels apart from stress, namely, malnutrition and limited access to prenatal care, due to curfews, border closures and road blocks, could affect birth weight. ${ }^{7}$ These channels are certainly negligible in our context. Finally, they only have 10 administrative districts, which makes difficult to use "standard" clustering methods, while we have instead 50 provinces.

Our study also breaks new ground by extending the analysis of the effects of terrorism in Spain to the realm of early life shocks, complementing the two main existing pieces of research on the economic and political consequences of terrorism in Spanish soil: The economic analysis of Abadie and Gardeazabal (2003) and the study by Montalvo (2011) on the electoral consequences of the Madrid train bombings of March 11 of $2004 .^{8}$

The rest of the paper proceeds as follows. Section 2 describes the main data sources and provide some descriptive statistics. Section 3 contains the empirical strategy. Section 4 presents the results of our analysis and a battery of extensions and robustness checks. Section 5 provides a conceptual framework to measure the "trade-off" between inputs in the production of child health and identifies the "marginal rate of technical transformation" in the production of child health between terrorist shocks and unemployment shocks. Finally, Section 6 concludes.

\footnotetext{
${ }^{7}$ For instance, they note that many women of reproductive age living in the Occupied Territories were not consuming sufficient meat, poultry and dairy products at the height of the al-Aqsa Intifada. They try to assess the importance of these channels.

${ }^{8}$ Abadie and Gardeazabal find that, after the outbreak of ETA-terrorism, per capita GDP in the Basque Country declined about 10 percentage points relative to a region without terrorism, while Montalvo shows that the Madrid train bombings of March 11 of 2004, the worst terrorist attack in Spain (with 191 deaths and more than 2000 injured), affected the electoral outcomes of the Spanish General Election celebrated 3 days after.
} 


\section{Data}

\subsection{Main Sources}

The national registry of live births in Spain (INE). ${ }^{9}$ The unit of observation in this dataset is the live birth. For each live birth, we have information on its date of occurrence (month and year), gender, weight, gestational length, and normality (whether there were complications during the pregnancy or labor). However, there is no information on other child health metrics such as Apgar score or head circumference. In addition, there is some demographic information on the mother of the child (province of residence, municipality size, place of delivery (home, hospital or clinic), age, parity history (number of births that she has had), marital status, and occupational status), but not on her risky behaviors (smoking or drinking), prenatal visits, educational attainment or (family) income. When appropriate, there is also information on his spouse: age and occupational status.

We use information on around 6.5 million births conceived between January 1980 and February 2003. ${ }^{10}$ Following previous work on the determinants of birth weight, we focus on mothers aged 15-49, exclude multiple births and those newborns whose weight was under 500 grams. ${ }^{11}$ Moreover, following Currie and Rossin-Slater (2013), those with gestational length below 26 weeks are also excluded.

The Victims of ETA Dataset (de la Calle and Sánchez-Cuenca). ${ }^{12}$ The unit of observation in this dataset is the ETA-victim casualty. It contains information on all casualties caused by ETA, and in particular bomb casualties, during the period 1960-2006. For each casualty there is information on the date (day, month and year) and region of occurrence.

\footnotetext{
${ }^{9}$ http: //www.ine.es

${ }^{10}$ Since conception length is not available for all live births, as a robustness check we also measure exposure using date of birth. We have almost 10 million births born between January 1980 and December 2003.

${ }^{11}$ Bhalotra and Clarke (2014) report that exposure to bomb casualties in the 2nd and 3rd trimester of pregnancy decreases the probability of twins.

${ }^{12}$ http: //www.march.es/ceacs/proyectos/dtv
} 


\subsection{Descriptive Statistics}

Some correlates. We begin our empirical analysis presenting some descriptive statistics (averages) on birth outcomes (panel A) and mother-pregnancy characteristics (panel B) by exposure to bomb casualties (over the whole period of analysis 1980-2003) during pregnancy in Table 1. This table has three columns. Column (1) displays the average of the corresponding variable in each row for children unexposed to bomb casualties during pregnancy, while column (2) focuses on children exposed to at least one bomb casualty during pregnancy. Column (3) contains the (mean) difference between the previous two columns (and its standard error).

[Insert Table 1 about here]

Panel A shows that children exposed to bomb casualties during pregnancy are on average 36 grams lighter; they are also 0.6 percentage points (or 6 per 1,000 live births) more likely to be low birth-weight babies and almost 2 percentage points (or 16 per 1,000 live births) less likely to be normal; they are 0.1 percentage points ( 1 per 1,000 live births) less likely to be males. Note that neither the fraction of available birth weights (non-missing values) nor the fraction of premature babies is related to exposure to bomb casualties during pregnancy.

Taken at face value, the estimates from panel A are consistent with exposure to terrorism while in utero affecting birth outcomes negatively. However, exposed and unexposed children may be different in many other dimensions apart from their exposure to bomb-casualties. For instance, in Panel B, we can see that mothers of babies exposed to bomb casualties are more than half a year older than mothers of unexposed babies, and their order of births are also different. In addition, these descriptive statistics are not informative about the relative importance of the timing of exposure (trimester of pregnancy). A rigorous analysis must account for the (precise) timing of exposure and use a proper identification strategy in order to gauge the impact of terrorism on birth outcomes. 


\subsection{Graphical Analysis}

Temporal variation. Figure 1 displays the quarterly evolution of bomb casualties and total casualties during the period Jan 1980-Feb 2003. Except for the peak in 1987 (the year of Hipercor bombing in Barcelona with 21 casualties), we can see that the evolution of bomb casualties fluctuates around a downward trend.

\section{[Insert Fig 1 about here]}

Spatial variation. Figure 2 describes the geographical dispersion of bomb casualties during the period Jan 1980-Feb 2003. While there are 4 focal points -the Basque Country, Catalunya, Comunidad de Madrid and Comunidad Valenciana-, several other regions were hit by bomb casualties. Figure 3 does the same for the total number of casualties.

[Insert Fig 2 about here]

[Insert Fig 3 about here]

Terrorism in the 1st trimester and child normality. As pointed out recently by Currie and Rossin-Slater (2013), measured effects of stressful events on birth weight, low birth-weight and prematurity may be sensitive to the econometric specification, and it is preferable to use sensitive indicators of newborn health, such as the probability of abnormal conditions of the newborn. If we plot the fraction of normal newborns against the number of bomb casualties in the fist trimester of pregnancy at the province-month-year level, we find a negative relationship. The gradient becomes stepper as we move from the full sample (including province-month-year cells with 0 casualties) in Fig 4 to the sample including cells with at least 10 casualties in Fig 7 .

[Insert Fig 4 about here]

[Insert Fig 5 about here]

[Insert Fig 6 about here]

[Insert Fig 7 about here] 


\section{$3 \quad$ Empirical Strategy}

\subsection{Difference-in-Difference}

Our main analysis is based on a difference-in-difference approach using multiple years of data, and measuring maternal exposure to terrorism during pregnancy by the number of bomb casualties at time $t$ (month-and-year-of-conception) in the mother's province of residence $p$ in each trimester of pregnancy. We then estimate regressions of the form

$$
\begin{aligned}
Y_{i, p, t}=\alpha+\beta_{1} \text { Casualties }_{p, t}^{1} & +\beta_{2} \text { Casualties }_{p, t}^{2}+\beta_{3} \text { Casualties }_{p, t}^{3} \\
& +\delta_{p}+\gamma_{t}+\left(\theta_{p} \times t\right)+\tau X_{i, p, t}+u_{i, p, t}
\end{aligned}
$$

where $Y_{i, p, t}$ is the birth outcome corresponding to newborn $i$, whose mother's province of residence is $p$, conceived in the year-month $t$, Casualties $s_{p, t}^{T}$ is the number of bomb casualties in trimester $T$ of pregnancy in province $p$, and $u_{i, p, t}$ is a random error term. Year-month of conception is estimated using the approach in Brown (2012): month of birth minus gestational age minus 2 weeks divided by 4 , and increased by 12 if the difference is less than 1. Conception year is then either the year of birth or the birth year less one if the conception month is larger than the birth month. ${ }^{13}$

Our most naïve regressions include both mother's province of residence fixed effects $\left(\delta_{p}\right)$ and year-month of conception fixed effects $\left(\gamma_{t}\right)$, while our most complete regressions include a vector of control variables $\left(X_{i, p, t}\right)$-birth order (parity) categories, mother's age categories, mother's marital status indicator, mother's occupational categories, father's occupational categories (with one category if not father), indicator for delivery in a hospital or clinic, and size of the municipality of residence categories- and province-specific linear time (yearmonth of conception) trends. The vector of parameters of interest is $\boldsymbol{\beta}=\left(\beta_{1}, \beta_{2}, \beta_{3}\right)$,

\footnotetext{
${ }^{13} 2$ weeks are subtracted because conception usually occurs 2 weeks after the last normal menstrual period.
} 
which measures the sensitivity of infant health to prenatal terrorist activity in each of the trimesters of pregnancy. Standard errors are clustered at the province level (50 provinces).

\subsection{Threats to our Identification Strategy}

Missing conception length. Since conception length is not available for all live births (it is missing for $32 \%$ of live births), we cannot measure exposure to terrorism for all live births by counting forward from date of conception. Still, for all live births we can measure exposure by counting backward from date of birth. This is the approach researchers are forced to rely on when length of gestation is not available (e.g., Bozzoli and QuintanaDomeque, 2014; Mansour and Rees, 2012). When defining exposure in this imperfect, alternative manner, we estimate regressions of the form

$$
\begin{array}{r}
Y_{i, p, t}=\widetilde{\alpha}+\widetilde{\beta}_{8-6} \text { Casualties }_{p, t}^{8-6}+\widetilde{\beta}_{5-3} \text { Casualties }_{p, t}^{5-3}+\widetilde{\beta}_{2-0} \text { Casualties }_{p, t}^{2-0} \\
+\widetilde{\delta}_{p}+\widetilde{\gamma}_{t}+\left(\widetilde{\theta}_{p} \times t\right)+\widetilde{\tau} X_{i, p, t}+\epsilon_{i, p, t}
\end{array}
$$

where $Y_{i, p, t}$ is the birth outcome corresponding to newborn $i$, whose mother's province of residence is $p$, born in the year-month $t$, Casualties $_{p, t}^{C-A}$ is the number of bomb casualties in $C$ to $A$ months before birth in province $p$, and $\epsilon_{i, p, t}$ is a random error term. Our most naïve regressions include both mother's province of residence fixed effects $\left(\widetilde{\delta}_{p}\right)$ and year-month of birth fixed effects $\left(\widetilde{\gamma}_{t}\right)$, while our most complete regressions include a vector of control variables $\left(X_{i, p, t}\right)$ and province-specific linear time (year-month of birth) trends. The vector of

parameters of interest now is $\widetilde{\boldsymbol{\beta}}=\left(\widetilde{\beta}_{8-6}, \widetilde{\beta}_{5-3}, \widetilde{\beta}_{2-0}\right)$, which measures the sensitivity of infant health to prenatal terrorist activity in each of the "approximately measured" trimesters of pregnancy. Note that we will also estimate equation (2) for the sample used in the estimation of equation (1), so that only the measurement of exposure changes, not the sample.

Confounding "economic" factors: the role of unemployment. One may be worried that our estimates of $\beta_{1}, \beta_{2}, \beta_{3}$ in equation (1) are biased by omitting measures of 
the economic situation (e.g., unemployment rates) in each of the trimesters of pregnancy. The role of unemployment rates at conception time or economic activity during pregnancy on birth outcomes have been previously studied. In the US, Dehejia and Lleras-Muney (2004) find that babies conceived in times of high unemployment had a reduced incidence of low birth weight -due to both selection and improvements in health behavior during recessions $^{14}$-, while Bozzoli and Quintana-Domeque (2014) find that babies who were exposed to lower economic activity during pregnancy in Argentina had a higher incidence of low birth weight. ${ }^{15}$ Hence, to account for the potential bias due to omitted economic factors we will estimate the following regressions

$$
\begin{gathered}
Y_{i, p, t}=\alpha+\beta_{1} \text { Casualties }_{p, t}^{1}+\beta_{2} \text { Casualties }_{p, t}^{2}+\beta_{3} \text { Casualties }_{p, t}^{3} \\
+\pi_{1} U R_{p, t}^{1}+\pi_{2} U R_{p, t}^{2}+\pi_{3} U R_{p, t}^{3}+\delta_{p}+\gamma_{t}+\left(\theta_{p} \times t\right)+\tau X_{i, p, t}+u_{i, p, t}
\end{gathered}
$$

where $U R_{p, t}^{T}$ is the unemployment rate in trimester $T$ of pregnancy in province $p$.

Spatial "spillover" effects. Implicit in our identification strategy is the assumption that the relevant "catchment area" for the impact of terrorism on birth outcomes is the mother's province of residence. However, it may well be that not only terrorist activity in the mother's province of residence but in neighboring provinces is relevant for birth outcomes. To account for these potential ("spillover") effects, we will assess the robustness of our estimates to include three additional variables that will capture bomb casualties occurring "close" to the mother's province of residence: (i) in neighboring (adjacent) provinces and (ii) within $300 \mathrm{~km}$ (which is a bit more than half the distance -60\%- between Barcelona and Madrid). We will estimate regressions of the form

\footnotetext{
${ }^{14}$ Aparicio and González (2013) find that in Spain babies are born healthier when the local unemployment rate is high.

${ }^{15}$ They exploit variation in mother's education and trimester of exposure to put forward tentative explanations in terms of maternal stress (affecting both low- and high-educated women) and nutrition (affecting only low-educated women).
} 


$$
\begin{array}{r}
Y_{i, p, t}=\alpha+\beta_{1} \text { Casualties }_{p, t}^{1}+\beta_{2} \text { Casualties }_{p, t}^{2}+\beta_{3} \text { Casualties }_{p, t}^{3} \\
+\pi_{1} U R_{p, t}^{1}+\pi_{2} U R_{p, t}^{2}+\pi_{3} U R_{p, t}^{3} \\
\text { }_{+\rho_{1} \text { Casualties }_{p, t}}^{1}+\rho_{2} \text { Casualties }_{p, t}^{2}+\rho_{3} \text { Casualties }_{p, t}^{3} \\
+\delta_{p}+\gamma_{t}+\left(\theta_{p} \times t\right)+\tau X_{i, p, t}+u_{i, p, t}
\end{array}
$$

where $\widetilde{C a s u a l t i e}_{p, t}^{T}$ is the number of bomb casualties in trimester $T$ of pregnancy close to province $p$ (e.g., within $300 \mathrm{~km}$, adjacent provinces).

Anticipation effects and placebo effects. If terrorist attacks were unexpected, we should not find that terrorist attacks after birth affect birth outcomes. We well assess this assumption by including the number of bomb casualties in the first trimester after birth. In addition, we will randomly allocate the number of bomb casualties and investigate its effects: by randomly allocating the number of bomb casualties we should not find an effect of terrorism on birth outcomes.

Functional form misspecification I: Non-linearities? Equation (1) assumes that the effect of bomb casualties on birth outcomes is linear. While this could be a reasonable approximation to the true functional form between birth outcomes and bomb casualties, we will investigate what happens when we depart from the assumption of linear effects.

Functional form misspecification II: Heterogeneous effects? Note that equation (1) also assumes that the effect of bomb casualties is homogeneous across regions, over time and for different family characteristics. However, one may be concerned that the effect of terrorism is region-specific or is concentrated in a particular time period or for families with certain characteristics. We will assess heterogeneous effects along these dimensions.

Selection effects: Fertility, Mortality and Migration. Terrorism may affect fertility decisions, and the direction of the effect could be either positive (if people spend more time in procreation activities at home) or negative (if people decide to postpone fertility). 
In addition, if still births increase as a consequence of terrorism (many of the bioactive mediators of maternal stress contribute to the pathophysiology of stillbirth), estimated effects of terrorism on birth outcomes for live births are likely to be lower bounds of the "true" effects (positive selection). ${ }^{16}$ Finally, terrorist activity may well be an important determinant of migration decisions: Abadie and Gardeazabal (2003), using the synthetic-control method approach, show how terrorism in the Basque Country transformed the patterns of population growh from positive to negative. Whether this is relevant or not for other Spanish regions can be explored using population data.

\section{Effects on Birth Outcomes for Live Births}

\subsection{Main Regressions}

Table 2 displays the main results of this paper. It contains a series of regressions for five different birth outcomes -birth weight (in grams), low birth-weight, normal, male and premature (indicators) - on the number of bomb casualties in each trimester of pregnancy grouped into three different panels (A, B, C).

[Insert Table 2 about here]

Starting with panel A, which includes mother's province of residence fixed effects and year-month of conception fixed effects, we can see that an additional bomb casualty in the first trimester of pregnancy (on average) decreases birth weight by around 0.7 grams, increases the expected number of low birth-weights by around 0.2 per 1,000 live births, decreases the predicted number of normal deliveries (without pregnancy or labor complications) by about 0.6 per 1,000 live births, and increases the number of premature babies

\footnotetext{
${ }^{16}$ Fetal Deaths Microdata available at http://www.ine.es/prodyser. We aggregate (count the number of) still births at the year-month-province level, so that the total number of observations is 13,900. Abortions (either spontaneous or voluntary pregnancy interruptions) could be affected by terrorism. Although there is yearly data on abortions (available from 1987) at the province level, its quality is debatable. Estimated effects of bomb casualties in a province on abortions one year later are available upon request.
} 
by 0.9 per 1,000 live births. In panel B we include socio-demographic controls -mother's age, birth order categories, mother's occupational categories, father's occupational categories, mother's marital status indicator, medical center/hospital delivery indicator, and municipality size categories- and obtain similar results, both qualitatively and quantitatively. ${ }^{17}$ Finally, to soak up any province-specific time trends, panel $\mathrm{C}$ adds the interaction of mother's province of residence fixed effects with a time trend (year-month of conception). Admittedly, the introduction of province specific year-month time trends kills most of the variation, perhaps too much. Remarkably enough, however, the statistical significance of our estimates survive to this stringent adjustment (except for the effect on prematurity). ${ }^{18}$ All point estimates remain in the same ballpark, but the one concerning average birth weight, which gets reduced to almost one third of its original magnitude.

The main takeaway of table 2 is that in utero exposure to terrorism early in pregnancy (1st trimester) has detrimental effects on birth outcomes. According to our most conservative estimates, and assuming linearity, ten additional bomb casualties would decrease average birth weight by about 3 grams (around 0.006 standard deviations) and increase low birth weight by about 1.5 per 1,000 live births. A more naïve picture would suggest instead effects of almost 7 grams (around 0.012 standard deviations) and about 1.9 per 1,000 live births. Both the magnitudes of estimated effects and the fact that they are found for the first trimester of pregnancy is consistent with the estimates available in the literature (Camacho, 2008; Brown, 2012; Mansour and Rees, 2012). ${ }^{19}$ If we break down the sample by gender, we find similar effects for both boys and girls. If anything, our results indicate stronger effects for girls. Results available upon request.

\footnotetext{
${ }^{17}$ Table A1 in the Appendix shows similar effects when using all casualties rather than only bomb casualties.

${ }^{18}$ If we control for the number of bomb casualties accumulated until pregnancy, our results are (if anything) stronger: average birth weight decreases by 0.5 grams per bomb casualty in the first trimester of pregnancy, while the fraction of normal babies decreases by 1.6 per thousand live births.

${ }^{19}$ The medical literature provides mixed evidence on the relative importance of early versus late pregnancy stress exposure (Schulte et al., 1990; de Weerth and Buitelaar, 2005; Hedegaard et al., 1993; Schneider et al., 1999). Economists tend to find that sources of acute maternal stress tend to affect birth outcomes negatively when they occur early in pregnancy.
} 


\subsection{Robustness checks}

\subsubsection{Observed date of birth versus estimated conception date}

Since conception length is not available for all live births, in Table 3 we estimate our most complete specification (i.e., with province-specific linear time trends), but using only information on the date of birth as a robustness check. The new point estimates (panel II) are qualitatively very similar (panel I), which is quite reassuring given both the different methodologies (date of birth versus date of conception) and the sample size discrepancies (10 million versus 6 million). It seems that, if anything, using date of birth rather than conception date results in attenuated estimated effects of terrorism on birth outcomes. Indeed, if we re-estimate the regressions based on date of birth for the same sample using date of conception (panel III), we get essentially attenuated results.

[Insert Table 3 about here]

\subsubsection{Confounding Economic Factors: In Utero Unemployment}

It is important to assess to what extent (if any) our trimester casualty variables are picking up the influence of economic fluctuations. We assess such a possibility in Table 4, where we include the (total) unemployment rate corresponding to each trimester of pregnancy using data from the Encuesta de Población Activa. ${ }^{20}$ Two results stand out in this table. First, our estimates are (almost) identical to those in Table 2 (panel C). Second, babies exposed to high unemployment rates (in the first trimester of pregnancy) have a reduced incidence of low birth weight - a finding consistent with the empirical evidence in the US (Deheija and Lleras-Muney, 2004) and Spain (Aparicio and González, 2013)-, tend to have a higher average birth weight, and are more likely to have a normal delivery (without complications).

[Insert Table 4 about here]

\footnotetext{
${ }^{20}$ http://www.ine.es/inebaseDYN/epa30308
} 


\subsubsection{Spatial "spillover" effects}

Table 5 shows that accounting for both unemployment rates in each trimester of pregnancy in the mother's province of residence and the bomb casualties in each trimester of pregnancy "close" to the mother's province of residence does not affect our results.

$$
\text { [Insert Table } 5 \text { about here] }
$$

\subsubsection{Falsification Tests}

Tables 6 and 7 present our falsification tests. In Table 6 we re-estimate our most complete econometric specification in Table 2 (panel C) for each birth outcome adding the number of bomb casualties in the first trimester after birth. If we were identifying unexpected terrorist attacks, we should not find that casualties after birth affect birth outcomes. The results in Table 2 show basically the same results as in Table 2 (panel C) and, reassuringly, none of the point estimates on the placebo variables is statistically significant, except for prematurity at the $10 \%$ level. ${ }^{21}$ What is more, controlling for the number of bomb casualties in the trimester before the 1st trimester of pregnancy does not affect our results (results available upon request).

\section{[Insert Table 6 about here]}

In Table 7, panel I, we collapse our data at the month-year-province level, and replicate panel A in Table 2 (weighting each cell by the number of observations/live births used in computing each mean at the month-year province level). Comparing panel I with panel II, we find that, when bomb casualties at the province-quarterly level are randomly allocated, we cannot reject that exposure to terrorism in the 1st trimester of pregnancy has a null effect on birth outcomes.

[Insert Table 7 about here]

\footnotetext{
${ }^{21}$ Similar results are obtained if we replace the number of bomb casualties in the first trimester after birth with those in the first nine months after birth.
} 


\subsubsection{Non-linearities}

So far we have been restricting the effect of bomb casualties to be linear. We now explore the effects of terrorism by intensity. In Table 8 we replace our count bomb casualties' variables with variables taking value 1 if the number of bomb casualties in the trimester is equal or higher than 10 (and 0 otherwise) in panel A, with variables taking value 1 if the number of bomb casualties in the trimester is equal or higher than 5 (and 0 otherwise) in panel $\mathrm{B}$, and with variables taking value 1 if the number of bomb casualties in the trimester is equal or higher than 1 (and 0 otherwise) in panel C. The results reveal that babies exposed in the first trimester of pregnancy to 10 casualties or more are on average (almost) 10 grams lighter. Similarly, the number of babies that are low birth-weight increases by (almost) 7 per 1,000 live births when exposed to 10 casualties or more during the first trimester of pregnancy. The evidence reported in this table indicates that "high intense terrorism" rather than "some terrorism" is the responsible for the previously estimated effects.

$$
\text { [Insert Table } 8 \text { about here] }
$$

\subsubsection{Heterogeneous Effects: Region, Time and Family}

By region: The Basque Country and Regions without Terrorism. One may wonder whether our estimates are driven by just one region (the Basque Country is the one with the highest level of terrorist activity) and its three provinces (Alava, Guipúzcoa, Vizcaya), so that the other provinces do not play any role in our analysis. Another observer could also raise the concern that "healthy mothers" (with better child health outcomes) may migrate in response to terrorism from the Basque Country to other regions, so that those exposed to terrorism in the Basque Country would tend to be negatively selected. If that were the case, we would be overestimating the effect of terrorism. While we cannot track mothers over time, we can nevertheless look at the evolution of aggregate population by province. Table 9 shows no evidence supporting any of these alternatives. Excluding the Basque Country, we still obtain the same empirical results as in Table 2 (Panel C). 
[Insert Table 9 about here]

By a similar token, we may inquire about what happens if we just focus on provinces with at least one bomb casualty, so that we exclude "safe" provinces. This amounts to excluding 35 out of 50 provinces. While clearly now clustered standard errors must be taken with a grain of salt, the point estimates reported in Table 9 are similar to the ones reported in panel $\mathrm{C}$ of Table $2 .^{22}$

By time period: 1985-1988 vs. 1980-1984 and 1989-2003. Is everything driven by a specific episode/period of violence, say in 1987 (the year of the Hipercor bombing)? Table 10 breaks down our sample into two periods: the period 1985-1988, which contains the peak of 1987, and the rest of our sample. The table shows that our findings do not appear to be driven by a specific episode/period of violence.

[Insert Table 10 about here]

By family characteristics: Armed forces vs. Others. The effects of being exposed to terrorism may well be heterogeneous across different demographic groups. One may think that those mothers whose husbands (partners) are in the police forces react with "more intensity" to bomb casualties in their region ("scarring"). However, one cannot discard the possibility that mothers who marry policemen have a greater capacity to cope with these dramatic events ("selection"). In the first case, we would expect bigger effects for this group of mothers. The opposite is expected in the second case. Unfortunately, our dataset does not allow us to identify whether husbands (partners) belong to the police force(s). Still, we known whether they are members of the armed forces. In Table 11 we break down our sample by father's armed-forces (occupation) status. The two subsamples are very different in size (1 to 75$)$, but the qualitative results would seem to indicate that the effects are much larger in magnitude for babies born to armed-forces fathers than their counterparts. In any case, the fact that our previous findings are not driven by newborns from armed forces families is reassuring for our identification strategy.

\footnotetext{
${ }^{22} p$-values using wild cluster-bootstrap are available upon request.
} 
[Insert Table 11 about here]

\subsubsection{Selection effects: Fertility, Mortality and Migration}

Part of the effects unveiled so far could be mediated, compensated or reinforced through selection effects due to behavioral responses, biological responses, or both. These selection effects may be driven by fertility changes, mortality effects or migration responses. Here, we investigate the relationship between "exposure to terrorism" and the number of live births, the number of fetal deaths (still births), and the female population size for the age group $25-54 .^{23}$

[Insert Table 12 about here]

Table 12 shows that bomb casualties in the previous year in a province does not explain either the population size of women or men aged 25-54, while unemployment rate in the previous year is a relevant determinant of population size. This is reassuring for our estimates, and not necessarily inconsistent with Abadie and Gardeazabal (2003). These authors focus on the onset of terrorism, without distinguishing the type of terrorism, and compare population growth in the Basque Country to that of a "synthetic cohort" (a weighted combination of other Spanish regions), while here we look at population levels in all different provinces, not just two.

\section{[Insert Table 13 about here]}

In Table 13 we investigate whether bomb casualties affect the number of live births. Bomb casualties in the three months before the first trimester of pregnancy ("conception period") increases the number of live births nine months after, while unemployment rate decreases it. In addition, exposure to terrorism in the 1st and 3rd trimester of pregnancies increases still births, while unemployment in the second and third trimesters decreases them.

\footnotetext{
${ }^{23}$ Population data obtained from Estimaciones Intercensales de Población (INE).
} 
Similar results are obtained when breaking down the analysis by gender (results available upon request).

Unfortunately, we do not have information on maternal behavior (e.g, smoking, drinking, physical exercise, diet, antenatal visits, etc.), so we cannot observe how exposure to bomb casualties ("exogenous" shocks) affects maternal inputs such as the number of cigarettes smoked, number of alcoholic beverages consumed, etc., and how they in turn shape child health. Still, suppose we observe some (but not all) of these inputs. A natural question to ask is: Can we recover the "marginal rate of technical substitution" between them in the production of child health? We address this (and other related questions) in the next section.

\section{On the Production of Child Health}

\subsection{Conceptual Framework with One measure of Child Health}

Suppose that we can classify babies as being healthy $(h=1)$ or unhealthy $(h=0)$, and that $h$ is a function of several observable inputs, denoted by the vector $\mathbf{x}$, and unobservable (to the econometrician) inputs, captured by $\eta$.

Assumption 1. The production function of child health is additively separable in $\mathbf{x}$ and $\eta$, but not necessarily linear in $\mathbf{x}$ :

$$
h=f(\mathbf{x})+\eta
$$

where $f$ is a smooth function and $\eta$ has mean zero.

Assumption 2. $\eta$ is mean independent of $\mathbf{x}$ :

$$
E[\eta \mid \mathbf{x}]=E[\eta]
$$

where $E$ is the expectation operator.

Result 1. Exact identification. Under assumptions 1 and 2, we can estimate the 
production function of child health non-parametrically, and recover the marginal rate of technical substitution between inputs $x_{k}$ and $x_{l}:^{24}$

$$
M R T S_{k, l}(\mathbf{x})=\frac{\frac{\partial f(\mathbf{x})}{\partial x_{k}}}{\frac{\partial f(\mathbf{x})}{\partial x_{l}}}
$$

This follows immediately, since under assumptions 1 and 2:

$$
E[h \mid \mathbf{x}]=f(\mathbf{x})
$$

Hence:

$$
\frac{\frac{\partial E[h \mid \mathbf{x}]}{\partial x_{k}}}{\frac{\partial E[h \mid \mathbf{x}]}{\partial x_{l}}}=\frac{\frac{\partial f(\mathbf{x})}{\partial x_{k}}}{\frac{\partial f(\mathbf{x})}{\partial x_{l}}}
$$

where the left-hand side of this equation can be recovered from the data; therefore the marginal rate of technical substitution between inputs $x_{k}$ and $x_{l}$ is exactly identified.

\subsection{Conceptual Framework with Multiple measures of Child Health}

(Child) health is a multidimensional concept. Hence, in reality, we do not observe $h$, but several proxies for (or dimensions of) $h$.

Assumption 3. $h_{g}$ is a proxy for (or dimension of) $h$ such that:

$$
h_{g}=v_{g}(h)+u_{g}
$$

where $v_{g}$ is a continuous function and $E\left[u_{g} \mid \mathbf{x}\right]=E\left[u_{g}\right]=0$.

Assumption 4. Strong separability of the link function:

$$
v_{g}(h)=v_{g}(f(\mathbf{x})+\eta)=v_{g}(f(\mathbf{x}))+v_{g}(\eta)
$$

where $E\left[v_{g}(\eta) \mid \mathbf{x}\right]=0$.

\footnotetext{
${ }^{24}$ How much $x_{k}$ have to decrease if $x_{l}$ increases by one extra unit to keep the same level of child health.
} 
Result 2. Over identification I. Under assumptions 1, 2, 3 and 4, the marginal rate of technical substitution between inputs $x_{k}$ and $x_{l}$ is over-identified, because

$$
E\left[h_{g} \mid \mathbf{x}\right]=v_{g}(f(\mathbf{x}))
$$

So that

$$
\frac{\frac{\partial E\left[h_{g} \mid \mathbf{x}\right]}{\partial x_{k}}}{\frac{\partial E\left[h_{g} \mid \mathbf{x}\right]}{\partial x_{l}}}=\frac{\frac{\partial f(\mathbf{x})}{\partial x_{k}}}{\frac{\partial f(\mathbf{x})}{\partial x_{l}}}=\operatorname{MRT} S_{k, l}(\mathbf{x})
$$

where the left-hand side of this equation can be recovered from the data. Since the righthand side of this expression does not depend on $g$, so neither should the left-hand side: therefore the marginal rate of technical substitution between inputs $x_{k}$ and $x_{l}$ is overidentified.

\subsection{Identification when observable inputs are unobserved}

The previous subsections assumed that observable inputs $\mathbf{x}$ were observed by the econometrician. Sometimes that is not the case. For example, when using administrative data, like in the present study. The question is then: What can be (over) identified (if anything) when instead of observing observable inputs $\mathbf{x}$, such as maternal smoking or maternal nutrition, we only observe (exogenous) shocks, such as unemployment shocks or terrorist attacks, to those inputs? For the sake of clarity in the exposition, we consider the case where the dimension of $\mathbf{x}$ is 2 , with both elements being unobserved, and two (exogenous) shocks $z_{1}$ and $z_{2}$ to inputs $x_{1}$ and $x_{2} \cdot{ }^{25}$

Assumption 5. The production of child health in terms of the 2 observed environmental factors can be written as:

$$
h=f\left(x_{1}\left(z_{1}, z_{2}\right), x_{2}\left(z_{1}, z_{2}\right)\right)+\eta
$$

\footnotetext{
${ }^{25}$ Note that $z_{1}$ and $z_{2}$ can affect either $x_{1}$ or $x_{2}$ or both.
} 
Result 3. Over identification II. Under assumptions 1, 2, 3, 4 and 5, the "marginal rate of technical substitution" between environmental factors $z_{1}$ and $z_{2}$ (i.e., how much $z_{1}$ have to decrease if $z_{2}$ increases by one extra unit to keep the same level of child health) is over-identified:

$$
\frac{\frac{\partial E\left[h_{g} \mid f\left(x_{1}\left(z_{1}, z_{2}\right), x_{2}\left(z_{1}, z_{2}\right)\right)\right]}{\partial z_{1}}}{\frac{\partial E\left[h_{g} \mid f\left(x_{1}\left(z_{1}, z_{2}\right), x_{2}\left(z_{1}, z_{2}\right)\right)\right.}{\partial z_{2}}}=\frac{\frac{\partial f}{\partial x_{1}} \frac{\partial x_{1}}{\partial z_{1}}+\frac{\partial f}{\partial x_{2}} \frac{\partial x_{2}}{\partial z_{1}}}{\frac{\partial f}{\partial x_{1}} \frac{\partial x_{1}}{\partial z_{2}}+\frac{\partial f}{\partial x_{2}} \frac{\partial x_{2}}{\partial z_{2}}}
$$

where, as before, the left-hand side of this equation can be recovered from the data. Since the right-hand side of this expression does not depend on $g$, so neither should the left-hand side: the "marginal rate of technical substitution" between environmental factors $z_{1}$ and $z_{2}$ is over-identified.

\subsection{Identification in practice: Terrorism, Unemployment and Child Health}

According to equation (15), the trade-off between (exogenous) environmental factors in the production of child health can be recovered from the data, and is over-identified. One can for instance simultaneously regress $h_{1}$ (say non low-birth weight status, i.e., one minus the LBW indicator) and $h_{2}$ (normality status) on the (exogenous) environmental factors at stake and the rest of control variables of panel $\mathrm{C}$ in Table 2 . In our case, these environmental factors are the number of bomb casualties in each trimester of pregnancy (Casualties ${ }^{1}$, Casualties $^{2}$, Casualties $\left.^{3}\right)$ and the unemployment rate in each trimester of pregnancy (Unemployment ${ }^{1}$, Unemployment ${ }^{2}$, Unemployment ${ }^{3}$ ). Once the estimation is performed one can test for (15).

[Insert Table 14 about here]

Table 14 shows that we cannot reject the equality of the ratios of the marginal effects of terrorism and unemployment in the first trimester of pregnancy for $h_{1}$ and $h_{2}$, so that the "marginal rate of technical substitution" between terrorism and unemployment in the production of child health is identified. 


\section{Conclusion}

We estimate the effect of in utero exposure to bomb casualties on a range of birth outcomes: birth weight, low-birth weight, normality, gender and prematurity. We find detrimental effects in terms of average birth weight (lower), the prevalence of low birth weight (higher) and the fraction of normal babies (lower). Our results are robust to a battery of robustness checks.

Crucially, and in support of our identification strategy, the number of bomb casualties after birth does not predict birth outcomes, and virtually the same estimates are obtained when controlling for economic conditions (as captured by total unemployment rates) and spatial "spillover" effects in each of the trimesters of pregnancy. We do not find evidence of migration responses (in terms of population sizes being related to last year terrorist activity), but the number of live births increases with the number of bomb casualties in the trimester before the first trimester of pregnancy, and the number of still births increases with the number of bomb casualties in the first and third trimesters of pregnancy. Given the increase in still births, the estimated effects of terrorism on birth outcomes for live births are likely to be downward biased (if anything) due to selective mortality.

Our results are driven by exposure to terrorism in the first trimester of pregnancy, indicating that bomb casualties could be acting as acute maternal stressors. That stress early in pregnancy (rather than in other periods) is an insult for the fetus is consistent with recent studies on the effects of "violence". However, we do not observe stress or any behavioral maternal response to it, such as whether women "smoke more" or "do less exercise" when exposed to a bomb casualty. If these were to be observed in the data, one should be able to disentangle behavioral from biological effects of terrorism on health at birth, as we have illustrated in the last part of this paper. 


\section{References}

Abadie, Alberto and Javier Gardeazabal. 2003. "The Economic Costs of Conflict: A Case Study of the Basque Country." American Economic Review 93 (1):113-132.

Almond, Douglas and Janet Currie. 2011. Human Capital Development before Age Five, Handbook of Labor Economics, vol. 4, chap. 15. Elsevier, 1315-1486.

Aparicio, Ainhoa and Libertad González. 2013. "Newborn health and the business cycle: Is it good to be born in bad times?" Universitat Pompeu Fabra, mimeo .

Becker, Gary and Yona Rubinstein. 2011. "Fear and the Response to Terrorism: An Economic Analysis." University of Chicago, mimeo .

Behrman, J. and M. Rosenzweig. 2004. "Returns to Birthweight." Review of Economics and Statistics 86 (2):586-601.

Beydoun, Hind and Audrey Saftlas. 2008. "Physical and Mental Health Outcomes of Prenatal Maternal Stress in Human and Animal Studies: A Review of Recent Evidence." Paediatric and Perinatal Epidemiology 22 (5):438-466.

Bhalotra, Sonia and Damian Clarke. 2014. "The Twins Instrument and Family Size." University of Essex, mimeo .

Black, Sandra, Paul Devereux, and Kjell Salvanes. 2007. "From the Cradle to the Labor Market? The Effect of Birth Weight on Adult Outcomes." Quarterly Journal of Economics 122 (1):409-439.

Bozzoli, Carlos and Climent Quintana-Domeque. 2014. "The Weight of the Crisis: Evidence from Newborns in Argentina." Review of Economics and Statistics 96 (3):550-562.

Bram, J., J. Orr, and C. Rapaport. 2002. "Measuring the Effect of the September 11 Attack on New York City." Federal Reserve Bank of New York Economic Policy Review 8:5-20. 
Brown, Ryan. 2012. "The Intergenerational Impact of Terror: Does the 9/11 Tragedy Reverberate into the Outcomes of the Next Generation." Duke University, mimeo .

Camacho, Adriana. 2008. "Stress and Birth Weight: Evidence from Terrorist Attacks." American Economic Review, Papers 8 Proceedings 98 (2):511-15.

Catalano, R., T. Bruckner, A. Marks, and B. Eskenazi. 2006. "Exogenous Shocks to the Human Sex Ratio: the Case of September 11, 2001 in New York City." Human Reproduction $21: 3127-3131$.

CIS. 2013. "Barómetro de la Percepción de los Principales Problemas de España." Available at http://www.cis.es. Accessed 13/02/2014.

Currie, Janet and Maya Rossin-Slater. 2013. "Weathering the storm: Hurricanes and birth outcomes." Journal of Health Economics 32 (3):487-503.

Currie, Janet and Hannes Schwandt. 2014. "The 9/11 Dust Cloud and Pregnancy Outcomes: A Reconsideration." NBER Working Paper. .

de la Calle, Luis and Ignacio Sánchez-Cuenca. 2006. "The Production of Terrorist Violence: Analyzing Target Selection Within the IRA and ETA." Working Paper. Instituto Juan March .

- 2007. "The Victims of ETA dataset." Available at http://www.march.es/ceacs/proyectos/dtv. Accessed 13/02/2014.

de Weerth, C. and J. Buitelaar. 2005. "Physiological Stress Recreativity in Human Pregnancy. A Review." Neuroscience and Behavioral Reviews 29:295-312.

Dehejia, Rajeev and Adriana Lleras-Muney. 2004. "Booms, Busts, and Babies' Health." The Quarterly Journal of Economics 119:1091-1130. 
Dunkel-Schetter, Chris. 2011. "Psychological science on pregnancy: Stress processes, biopsychosocial models, and emerging research issues." Annual Review of Psychology 62 (2):531558.

Dustmann, Christian and Francesco Fasani. 2014. "The Effect of Local Area Crime on Mental Health." Economic Journal, forthcoming .

Heckman, James. 2007. "The economics, technology, and neuroscience of human capability formation." PNAS 104 (33):13250-13255.

Hedegaard, M., T. Henriksen, S. Sabore, and N. Secher. 1993. "Physiological Distress in Pregnancy and Preterm Delivery." British Medical Journal 307:234-239.

Krueger, Alan. 2007. What Makes a Terrorist. Economics and the Roots of Terrorism. Princeton University Press.

LaFree, Gary, Laura Dugan, Min Xie, and Piyusha Singh. 2012. "Spatial and Temporal Patterns of Terrorist Attacks by ETA 1970 to 2007." Journal of Quantitative Criminology $28: 7-29$.

Landrigan, P. 2001. "Health Consequences of the 11 September 2001 Attacks." Environmental Health Perspectives 109:A514-15.

Mansour, Hani and Daniel I. Rees. 2012. "Armed conflict and birth weight: Evidence from the al-Aqsa Intifada." Journal of Development Economics 99 (1):190-199.

McCormick, Marie C. 1985. "The Contribution of Low Birth Weight to Infant Mortality and Childhood Morbidity." New England Journal of Medicine 312 (2):82-90.

Montalvo, Jose G. 2011. "Voting after the bombings: A natural experiment on the effect of terrorist attacks on democratic elections." Review of Economics and Statistics $93(4): 1146-1154$. 
Nijdam, Mirjam J., Berthold P. R. Gersons, and Miranda Olff. 2010. "Dutch politicians' coping with terrorist threat." The British Journal of Psychiatry 197 (4):328-329.

Pollack, Raphael and Michael Divon. 1992. "Intrauterine Growth Retardation: Definition, Classification, and Etiology." Clinical Obstetrics and Gynecology 35 (1):99-107.

Saul, Ben. 2012. "The Challenge of Defining Terrorism." Available at http://www.isn.ethz.ch. Accessed 13/02/2014.

Schneider, M., E. Roughton, A. Koehler, and G. Lubach. 1999. "Growth and Development following Prenatal Stress Exposure in Primates: An Examination of Ontogenetic Vulnerability." Child Development 70 (2):263-274.

Schulte, H., D. Weisner, and B. Allolio. 1990. "The Cortricotropin Releasing Hormone Test in Late Pregnancy: Lack of Adrenocorticotropin and Cortisol Response." Clinical Endocrinology 33 (1):99-106. 


\section{Tables and Figures}

Table 1: Descriptive Statistics

\begin{tabular}{|c|c|c|c|}
\hline A. Birth Outcomes & $\begin{array}{l}\text { No Bomb } \\
\text { Casualty } \\
\end{array}$ & $\begin{array}{c}\text { Bomb } \\
\text { Casualties } \geq 1 \\
\end{array}$ & Difference \\
\hline $\mathrm{BW}(500-6,590 \mathrm{~g})^{a}$ & $3,291.64$ & $3,255.78$ & $\begin{array}{c}-35.86^{* * *} \\
(8.28)\end{array}$ \\
\hline BW is available & 0.95 & 0.95 & $\begin{array}{c}0.00 \\
(0.011)\end{array}$ \\
\hline $\mathrm{LBW}(1 \text { if } \mathrm{BW} \leq 2,500 \mathrm{~g})^{a}$ & 0.051 & 0.057 & $\begin{array}{c}0.006^{* * * *} \\
(0.001)\end{array}$ \\
\hline Premature & 0.047 & 0.050 & $\begin{array}{c}0.003 \\
(0.004)\end{array}$ \\
\hline Normal & 0.899 & 0.883 & $\begin{array}{c}-0.016^{*} \\
(0.009)\end{array}$ \\
\hline Male & 0.517 & 0.516 & $\begin{array}{l}-0.001^{*} \\
(0.0004)\end{array}$ \\
\hline \multicolumn{4}{|c|}{ B. Mother \& Pregnancy Characteristics } \\
\hline Mother's age (15-49) & 28.8 & 29.4 & $\begin{array}{c}0.6^{* * * *} \\
(0.2)\end{array}$ \\
\hline Mother is married & 0.883 & 0.879 & $\begin{array}{l}-0.004 \\
(0.009)\end{array}$ \\
\hline First pregnancy & 0.519 & 0.508 & $\begin{array}{l}-0.011 \\
(0.009)\end{array}$ \\
\hline Second pregnancy & 0.364 & 0.347 & $\begin{aligned}-0.017^{* * *} & (0.006)\end{aligned}$ \\
\hline
\end{tabular}

Note: Live births conceived between January 1980 and February 2003.

Statistical difference based on a $t$-test.

${ }^{a} \mathrm{~N}=6,327,753$. Otherwise $\mathrm{N}=6,641,478$

Standard errors clustered at the province level (50 provinces).

${ }^{* * *} p-$ value $<0.01,{ }^{* *} p-$ value $<0.05,{ }^{*} p-$ value $<0.1$ 
Table 2: Regressions of Birth Outcomes on Bomb casualties

(prenatal exposure measured counting forward from estimated conception date)

\begin{tabular}{|c|c|c|c|c|c|}
\hline A. Year-Month FE \& Province FE & $\begin{array}{c}\text { BW } \\
\text { (in grams) }\end{array}$ & $\begin{array}{c}\text { LBW } \\
\text { (per } 1,000)\end{array}$ & $\begin{array}{c}\text { Normal } \\
(\text { per } 1,000)\end{array}$ & $\begin{array}{c}\text { Male } \\
(\text { per } 1,000)\end{array}$ & $\begin{array}{l}\text { Premature } \\
\text { (per } 1,000)\end{array}$ \\
\hline Bomb Casualties 1st trimester of pregnancy & $\begin{array}{c}-0.674^{* * *} \\
(0.194)\end{array}$ & $\begin{array}{c}0.187^{* *} \\
(0.083)\end{array}$ & $\begin{array}{c}-0.631^{* * *} \\
(0.194)\end{array}$ & $\begin{array}{l}-0.138 \\
(0.123)\end{array}$ & $\begin{array}{c}0.976^{* *} \\
(0.468)\end{array}$ \\
\hline Bomb Casualties 2nd trimester of pregnancy & $\begin{array}{l}-0.504 \\
(0.404)\end{array}$ & $\begin{array}{l}-0.118 \\
(0.148)\end{array}$ & $\begin{array}{l}-0.287 \\
(0.275)\end{array}$ & $\begin{array}{l}-0.379 \\
(0.230)\end{array}$ & $\begin{array}{l}0.311^{*} \\
(0.171)\end{array}$ \\
\hline Bomb Casualties 3rd trimester of pregnancy & $\begin{array}{l}-0.392 \\
(0.484)\end{array}$ & $\begin{array}{c}0.017 \\
(0.105)\end{array}$ & $\begin{array}{c}0.252 \\
(0.454)\end{array}$ & $\begin{array}{c}0.276 \\
(0.212)\end{array}$ & $\begin{array}{l}-0.029 \\
(0.266)\end{array}$ \\
\hline Number of live births & $6,327,753$ & $6,327,753$ & $6,641,478$ & $6,641,478$ & $6,641,478$ \\
\hline
\end{tabular}

\section{B. (A) \& Socio-Demographic Controls}

\begin{tabular}{|c|c|c|c|c|c|}
\hline Bomb Casualties 1st trimester of pregnancy & $\begin{array}{c}-0.725^{* * *} \\
(0.198)\end{array}$ & $\begin{array}{c}0.208^{* *} \\
(0.088)\end{array}$ & $\begin{array}{c}-0.571^{* * *} \\
(0.187)\end{array}$ & $\begin{array}{l}-0.130 \\
(0.126)\end{array}$ & $\begin{array}{c}0.943^{* *} \\
(0.457)\end{array}$ \\
\hline Bomb Casualties 2nd trimester of pregnancy & $\begin{array}{l}-0.489 \\
(0.380)\end{array}$ & $\begin{array}{l}-0.119 \\
(0.154)\end{array}$ & $\begin{array}{l}-0.173 \\
(0.275)\end{array}$ & $\begin{array}{l}-0.376 \\
(0.232)\end{array}$ & $\begin{array}{c}0.272 \\
(0.167)\end{array}$ \\
\hline Bomb Casualties 3rd trimester of pregnancy & $\begin{array}{l}-0.411 \\
(0.460)\end{array}$ & $\begin{array}{c}0.025 \\
(0.106)\end{array}$ & $\begin{array}{c}0.392 \\
(0.434)\end{array}$ & $\begin{array}{c}-0.274 \\
(0.214)\end{array}$ & $\begin{array}{l}-0.070 \\
(0.260)\end{array}$ \\
\hline Number of live births & $6,295,035$ & $6,295,035$ & $6,607,470$ & $6,607,470$ & $6,607,470$ \\
\hline
\end{tabular}

\section{C. (B) \& Province-Specific Linear Year-Month Trends}

Bomb Casualties 1st trimester of pregnancy

Bomb Casualties 2nd trimester of pregnancy

Bomb Casualties 3rd trimester of pregnancy

\begin{tabular}{ccccc}
$-0.278^{* *}$ & $0.145^{* *}$ & $-0.671^{* * *}$ & -0.093 & 0.653 \\
$(0.122)$ & $(0.061)$ & $(0.179)$ & $(0.120)$ & $(0.407)$ \\
& & & & \\
-0.055 & -0.179 & $-0.272^{* * *}$ & -0.337 & 0.027 \\
$(0.202)$ & $(0.144)$ & $(0.098)$ & $(0.236)$ & $(0.099)$ \\
& & & & \\
0.148 & -0.055 & 0.253 & -0.228 & $-0.410^{*}$ \\
$(0.250)$ & $(0.078)$ & $(0.174)$ & $(0.212)$ & $(0.215)$ \\
\hline $6,295,035$ & $6,295,035$ & $6,607,470$ & $6,607,470$ & $6,607,470$
\end{tabular}

\begin{tabular}{lllll}
\hline Number of live births & $6,295,035$ & $6,295,035$ & $6,607,470$ & $6,607,470$ \\
\hline
\end{tabular}

Note: Live births conceived between January 1980 and February 2003.

Standard errors clustered at the province level (50 provinces).

${ }^{* * *} p-$ value $<0.01,{ }^{* *} p-$ value $<0.05,{ }^{*} p-$ value $<0.1$ 
Table 3: Regressions of Birth Outcomes on Bomb casualties: conception date vs. date of birth

\begin{tabular}{|c|c|c|c|c|c|}
\hline & $\begin{array}{c}\text { BW } \\
\text { (in grams) }\end{array}$ & $\begin{array}{c}\text { LBW } \\
\text { (per } 1,000)\end{array}$ & $\begin{array}{c}\text { Normal } \\
(\text { per } 1,000)\end{array}$ & $\begin{array}{c}\text { Male } \\
\text { (per } 1,000)\end{array}$ & $\begin{array}{l}\text { Premature } \\
\text { (per } 1,000)\end{array}$ \\
\hline I. Prenatal exposure using date of conception & & & & & \\
\hline Bomb Casualties 1st trimester of pregnancy & $\begin{array}{c}-0.278^{* *} \\
(0.122)\end{array}$ & $\begin{array}{c}0.145^{* *} \\
(0.061)\end{array}$ & $\begin{array}{c}-0.671^{* * *} \\
(0.179)\end{array}$ & $\begin{array}{l}-0.093 \\
(0.120)\end{array}$ & $\begin{array}{c}0.653 \\
(0.407)\end{array}$ \\
\hline Bomb Casualties 2nd trimester of pregnancy & $\begin{array}{l}-0.055 \\
(0.202)\end{array}$ & $\begin{array}{l}-0.179 \\
(0.144)\end{array}$ & $\begin{array}{c}-0.272^{* * *} \\
(0.098)\end{array}$ & $\begin{array}{l}-0.337 \\
(0.236)\end{array}$ & $\begin{array}{c}0.027 \\
(0.099)\end{array}$ \\
\hline Bomb Casualties 3rd trimester of pregnancy & $\begin{array}{c}0.148 \\
(0.250)\end{array}$ & $\begin{array}{l}-0.055 \\
(0.078)\end{array}$ & $\begin{array}{c}0.253 \\
(0.174)\end{array}$ & $\begin{array}{l}-0.228 \\
(0.212)\end{array}$ & $\begin{array}{c}-0.410^{*} \\
(0.215)\end{array}$ \\
\hline Number of live births & $6,295,035$ & $6,295,035$ & $6,607,470$ & $6,607,470$ & $6,607,470$ \\
\hline \multicolumn{6}{|l|}{ II. Prenatal exposure using date of birth } \\
\hline Bomb Casualties 6-8 months before birth & $\begin{array}{c}-0.211^{*} \\
(0.116)\end{array}$ & $\begin{array}{c}0.067 \\
(0.058)\end{array}$ & $\begin{array}{c}-0.396^{* * *} \\
(0.213)\end{array}$ & $\begin{array}{l}-0.040 \\
(0.088)\end{array}$ & $\begin{array}{c}0.169 \\
(0.208)\end{array}$ \\
\hline Bomb Casualties 3-5 months before birth & $\begin{array}{l}-0.193 \\
(0.149)\end{array}$ & $\begin{array}{l}-0.000 \\
(0.116)\end{array}$ & $\begin{array}{l}-0.018 \\
(0.180)\end{array}$ & $\begin{array}{l}-0.218 \\
(0.215)\end{array}$ & $\begin{array}{c}0.314 \\
(0.210)\end{array}$ \\
\hline Bomb Casualties 0-2 months before birth & $\begin{array}{c}0.391 \\
(0.312)\end{array}$ & $\begin{array}{l}-0.034 \\
(0.104)\end{array}$ & $\begin{array}{l}-0.128 \\
(0.130)\end{array}$ & $\begin{array}{l}-0.210 \\
(0.203)\end{array}$ & $\begin{array}{l}-0.007 \\
(0.168)\end{array}$ \\
\hline Number of live births & $8,368,967$ & $8,368,967$ & $9,789,870$ & $9,789,870$ & $9,789,870$ \\
\hline
\end{tabular}

III. Prenatal exposure using date of birth (sample in I)

\begin{tabular}{|c|c|c|c|c|c|}
\hline Bomb Casualties 6-8 months before birth & $\begin{array}{l}-0.159 \\
(0.149)\end{array}$ & $\begin{array}{c}0.024 \\
(0.050)\end{array}$ & $\begin{array}{c}-0.543^{* * *} \\
(0.144)\end{array}$ & $\begin{array}{l}-0.141 \\
(0.123)\end{array}$ & $\begin{array}{c}0.436 \\
(0.358)\end{array}$ \\
\hline Bomb Casualties 3-5 months before birth & $\begin{array}{l}-0.196 \\
(0.158)\end{array}$ & $\begin{array}{l}-0.060 \\
(0.126)\end{array}$ & $\begin{array}{c}0.149 \\
(0.152)\end{array}$ & $\begin{array}{l}-0.286 \\
(0.318)\end{array}$ & $\begin{array}{c}0.198 \\
(0.188)\end{array}$ \\
\hline Bomb Casualties 0-2 months before birth & $\begin{array}{c}0.565 \\
(0.375)\end{array}$ & $\begin{array}{l}-0.068 \\
(0.105)\end{array}$ & $\begin{array}{c}0.084 \\
(0.140)\end{array}$ & $\begin{array}{c}-0.309^{* * *} \\
(0.115)\end{array}$ & $\begin{array}{c}-0,340^{*} \\
(0.197)\end{array}$ \\
\hline Number of live births & $6,295,035$ & $6,295,035$ & $6,607,470$ & $6,607,470$ & $6,607,470$ \\
\hline
\end{tabular}

Note: Live births conceived between January 1980 and February 2003

Econometric specification: Panel C, Table 2.

Standard errors clustered at the province level (50 provinces).

${ }^{* * *} p-$ value $<0.01,{ }^{* *} p-$ value $<0.05,{ }^{*} p-$ value $<0.1$ 
Table 4: Regressions of Birth Outcomes on Bomb Casualties and Unemployment Rates

\begin{tabular}{|c|c|c|c|c|c|}
\hline & $\begin{array}{c}\text { BW } \\
\text { (in grams) }\end{array}$ & $\begin{array}{c}\text { LBW } \\
\text { (per } 1,000)\end{array}$ & $\begin{array}{c}\text { Normal } \\
(\text { per } 1,000)\end{array}$ & $\begin{array}{c}\text { Male } \\
\text { (per } 1,000)\end{array}$ & $\begin{array}{l}\text { Premature } \\
\text { (per } 1,000)\end{array}$ \\
\hline Bomb Casualties 1st trimester of pregnancy & $\begin{array}{c}-0.251^{*} \\
(0.127)\end{array}$ & $\begin{array}{c}0.146^{* *} \\
(0.059)\end{array}$ & $\begin{array}{c}-0.618^{* * *} \\
(0.161)\end{array}$ & $\begin{array}{l}-0.090 \\
(0.120)\end{array}$ & $\begin{array}{c}0.662 \\
(0.408)\end{array}$ \\
\hline Bomb Casualties 2nd trimester of pregnancy & $\begin{array}{l}-0.038 \\
(0.188)\end{array}$ & $\begin{array}{l}-0.181 \\
(0.139)\end{array}$ & $\begin{array}{c}-0.246^{* *} \\
(0.108)\end{array}$ & $\begin{array}{l}-0.339 \\
(0.236)\end{array}$ & $\begin{array}{l}-0.020 \\
(0.101)\end{array}$ \\
\hline Bomb Casualties 3rd trimester of pregnancy & $\begin{array}{c}0.154 \\
(0.231)\end{array}$ & $\begin{array}{l}-0.055 \\
(0.076)\end{array}$ & $\begin{array}{c}0.269 \\
(0.203)\end{array}$ & $\begin{array}{l}-0.224 \\
(0.217)\end{array}$ & $\begin{array}{c}-0.410^{*} \\
(0.219)\end{array}$ \\
\hline Unemployment rate 1st trimester of pregnancy & $\begin{array}{l}0.628^{*} \\
(0.315)\end{array}$ & $\begin{array}{c}-0.209^{* *} \\
(0.093)\end{array}$ & $\begin{array}{l}0.721^{*} \\
(0.394)\end{array}$ & $\begin{array}{l}-0.001 \\
(0.155)\end{array}$ & $\begin{array}{c}0.178 \\
(0.176)\end{array}$ \\
\hline Unemployment rate 2 nd trimester of pregnancy & $\begin{array}{l}-0.013 \\
(0.240)\end{array}$ & $\begin{array}{c}0.138 \\
(0.111)\end{array}$ & $\begin{array}{l}0.283^{*} \\
(0.158)\end{array}$ & $\begin{array}{c}0.241 \\
(0.236)\end{array}$ & $\begin{array}{l}-0.138 \\
(0.146)\end{array}$ \\
\hline Unemployment rate $3 \mathrm{rd}$ trimester of pregnancy & $\begin{array}{c}0.399 \\
(0.325)\end{array}$ & $\begin{array}{l}-0.015 \\
(0.099)\end{array}$ & $\begin{array}{c}0.603 \\
(0.566)\end{array}$ & $\begin{array}{l}-0.100 \\
(0.152)\end{array}$ & $\begin{array}{c}0.207^{* *} \\
(0.099)\end{array}$ \\
\hline Number of live births & $6,295,035$ & $6,295,035$ & $6,607,470$ & $6,607,470$ & $6,607,470$ \\
\hline
\end{tabular}

Note: Live births conceived between January 1980 and February 2003.

Econometric specification: Panel C, Table 2.

Standard errors clustered at the province level (50 provinces).

${ }^{* * *} p-$ value $<0.01,{ }^{* *} p-$ value $<0.05,{ }^{*} p-$ value $<0.1$ 
Table 5: Regressions of Birth Outcomes on Bomb Casualties accounting for spatial "spillover" effects

\begin{tabular}{|c|c|c|c|c|c|}
\hline I. Bomb Casualties in Adjacent Provinces & $\begin{array}{c}\text { BW } \\
\text { (in grams) }\end{array}$ & $\begin{array}{c}\text { LBW } \\
\text { (per } 1,000)\end{array}$ & $\begin{array}{c}\text { Normal } \\
(\text { per } 1,000)\end{array}$ & $\begin{array}{c}\text { Male } \\
\text { (per } 1,000)\end{array}$ & $\begin{array}{l}\text { Premature } \\
\text { (per } 1,000)\end{array}$ \\
\hline Bomb Casualties 1st trimester of pregnancy & $\begin{array}{c}-0.251^{* *} \\
(0.126)\end{array}$ & $\begin{array}{c}0.140^{* *} \\
(0.058)\end{array}$ & $\begin{array}{c}-0.621^{* * *} \\
(0.159)\end{array}$ & $\begin{array}{l}-0.095 \\
(0.123)\end{array}$ & $\begin{array}{c}0.665 \\
(0.405)\end{array}$ \\
\hline Bomb Casualties 2nd trimester of pregnancy & $\begin{array}{l}-0.037 \\
(0.190)\end{array}$ & $\begin{array}{l}-0.191 \\
(0.138)\end{array}$ & $\begin{array}{c}-0.247^{* *} \\
(0.112)\end{array}$ & $\begin{array}{l}-0.339 \\
(0.236)\end{array}$ & $\begin{array}{l}-0.013 \\
(0.100)\end{array}$ \\
\hline Bomb Casualties 3rd trimester of pregnancy & $\begin{array}{c}0.151 \\
(0.231)\end{array}$ & $\begin{array}{l}-0.054 \\
(0.075)\end{array}$ & $\begin{array}{c}0.274 \\
(0.210)\end{array}$ & $\begin{array}{l}-0.227 \\
(0.217)\end{array}$ & $\begin{array}{c}-0.399^{*} \\
(0.220)\end{array}$ \\
\hline Number of live births & $6,295,035$ & $6,295,035$ & $6,607,470$ & $6,607,470$ & $6,607,470$ \\
\hline II. Bomb Casualties within $300 \mathrm{~km}$ & & & & & \\
\hline Bomb Casualties 1st trimester of pregnancy & $\begin{array}{c}-0.284^{* *} \\
(0.128)\end{array}$ & $\begin{array}{c}0.149 * * \\
(0.072)\end{array}$ & $\begin{array}{c}-0.621^{* * *} \\
(0.176)\end{array}$ & $\begin{array}{l}-0.052 \\
(0.121)\end{array}$ & $\begin{array}{c}0.661 \\
(0.427)\end{array}$ \\
\hline Bomb Casualties 2nd trimester of pregnancy & $\begin{array}{l}-0.067 \\
(0.195)\end{array}$ & $\begin{array}{l}-0.225 \\
(0.160)\end{array}$ & $\begin{array}{c}-0.218^{*} \\
(0.119)\end{array}$ & $\begin{array}{l}-0.351 \\
(0.239)\end{array}$ & $\begin{array}{l}-0.003 \\
(0.110)\end{array}$ \\
\hline Bomb Casualties 3rd trimester of pregnancy & $\begin{array}{c}0.160 \\
(0.238)\end{array}$ & $\begin{array}{l}-0.068 \\
(0.084)\end{array}$ & $\begin{array}{c}0.277 \\
(0.217)\end{array}$ & $\begin{array}{l}-0.256 \\
(0.230)\end{array}$ & $\begin{array}{c}-0.390^{*} \\
(0.228)\end{array}$ \\
\hline Number of live births & $6,295,035$ & $6,295,035$ & $6,607,470$ & $6,607,470$ & $6,607,470$ \\
\hline
\end{tabular}

Note: Live births conceived between January 1980 and February 2003.

Econometric specification: Table $4+$ indirect treatment effects (see equation (4) in the text).

Standard errors clustered at the province level (50 provinces).

${ }^{* * *} p-$ value $<0.01,{ }^{* *} p-$ value $<0.05,{ }^{*} p-$ value $<0.1$ 
Table 6: Regressions of Birth Outcomes on ETA-Bomb casualties during pregnancy and after birth

\begin{tabular}{|c|c|c|c|c|c|}
\hline & $\begin{array}{c}\text { BW } \\
\text { (in grams) }\end{array}$ & $\begin{array}{c}\text { LBW } \\
\text { (per } 1,000)\end{array}$ & $\begin{array}{c}\text { Normal } \\
\text { (per } 1,000)\end{array}$ & $\begin{array}{c}\text { Male } \\
\text { (per } 1,000)\end{array}$ & $\begin{array}{l}\text { Premature } \\
\text { (per } 1,000)\end{array}$ \\
\hline Bomb Casualties 1st trimester of pregnancy & $\begin{array}{c}-0.271^{* *} \\
(0.119)\end{array}$ & $\begin{array}{c}0.142^{* *} \\
(0.063)\end{array}$ & $\begin{array}{c}-0.671^{* * *} \\
(0.182)\end{array}$ & $\begin{array}{l}-0.090 \\
(0.120)\end{array}$ & $\begin{array}{c}0.645 \\
(0.410)\end{array}$ \\
\hline Bomb Casualties 2nd trimester of pregnancy & $\begin{array}{l}-0.054 \\
(0.204)\end{array}$ & $\begin{array}{l}-0.179 \\
(0.145)\end{array}$ & $\begin{array}{c}-0.272^{* * *} \\
(0.098)\end{array}$ & $\begin{array}{l}-0.337 \\
(0.235)\end{array}$ & $\begin{array}{l}-0.027 \\
(0.100)\end{array}$ \\
\hline Bomb Casualties 3rd trimester of pregnancy & $\begin{array}{c}0.140 \\
(0.242)\end{array}$ & $\begin{array}{l}-0.053 \\
(0.076)\end{array}$ & $\begin{array}{c}0.253 \\
(0.175)\end{array}$ & $\begin{array}{l}-0.232 \\
(0.211)\end{array}$ & $\begin{array}{c}-0.400^{*} \\
(0.212)\end{array}$ \\
\hline Placebo: Bomb Casualties 1st trimester after birth & $\begin{array}{c}0.294 \\
(0.365)\end{array}$ & $\begin{array}{l}-0.087 \\
(0.132)\end{array}$ & $\begin{array}{c}0.007 \\
(0.149)\end{array}$ & $\begin{array}{c}0.103 \\
(0.069)\end{array}$ & $\begin{array}{c}-0.332^{*} \\
(0.170)\end{array}$ \\
\hline Number of live births & $6,295,035$ & $6,295,035$ & $6,607,470$ & $6,607,470$ & $6,607,470$ \\
\hline
\end{tabular}

Note: Live births conceived between January 1980 and February 2003.

Econometric specification: Panel C, Table 2.

Standard errors clustered at the province level (50 provinces).

${ }^{* * *} p-$ value $<0.01,{ }^{* *} p-$ value $<0.05,{ }^{*} p-$ value $<0.1$ 
Table 7: Regressions of Birth Outcomes on Bomb casualties

\begin{tabular}{|c|c|c|c|c|c|}
\hline I. Collapsed: Observed bomb casualties & $\begin{array}{c}\text { BW } \\
\text { (in grams) }\end{array}$ & $\begin{array}{c}\text { LBW } \\
\text { (per } 1,000)\end{array}$ & $\begin{array}{c}\text { Normal } \\
(\text { per } 1,000)\end{array}$ & $\begin{array}{c}\text { Male } \\
(\text { per } 1,000)\end{array}$ & $\begin{array}{l}\text { Premature } \\
\text { (per 1,000) }\end{array}$ \\
\hline Bomb Casualties 1st trimester of pregnancy & $\begin{array}{c}-0.674^{* * *} \\
(0.196)\end{array}$ & $\begin{array}{c}0.187 * * \\
(0.085)\end{array}$ & $\begin{array}{c}-0.631^{* * *} \\
(0.196)\end{array}$ & $\begin{array}{l}-0.138 \\
(0.125)\end{array}$ & $\begin{array}{c}0.976^{* *} \\
(0.473)\end{array}$ \\
\hline Bomb Casualties 2nd trimester of pregnancy & $\begin{array}{l}-0.504 \\
(0.409)\end{array}$ & $\begin{array}{l}-0.118 \\
(0.150)\end{array}$ & $\begin{array}{l}-0.287 \\
(0.279)\end{array}$ & $\begin{array}{l}-0.379 \\
(0.233)\end{array}$ & $\begin{array}{l}0.311^{*} \\
(0.173)\end{array}$ \\
\hline Bomb Casualties 3rd trimester of pregnancy & $\begin{array}{l}-0.392 \\
(0.489)\end{array}$ & $\begin{array}{c}0.017 \\
(0.106)\end{array}$ & $\begin{array}{c}0.252 \\
(0.459)\end{array}$ & $\begin{array}{c}0.276 \\
(0.215)\end{array}$ & $\begin{array}{l}-0.029 \\
(0.269)\end{array}$ \\
\hline
\end{tabular}

F-test coefficients in 1st row all equal zero

Ho: No effect of 1st trimester of pregnancy

$$
F_{5,45}=5.93
$$

$p-$ value $=0.0003$

\begin{tabular}{lllll}
\hline Observations (month-year-province cells) & 13,900 & 13,900 & 13,900 & 13,900
\end{tabular}

II. Collapsed: Randomized bomb casualties

Bomb Casualties 1st trimester of pregnancy

$\begin{array}{ccccc}-0.058 & -0.077 & 0.171 & -0.467 & -0.469^{*} \\ (0.604) & (0.170) & (0.381) & (0.398) & (0.235) \\ -0.493 & -0.334 & -0.225 & -0.243 & -0.247 \\ (0.448) & (0.265) & (0.426) & (0.290) & (0.220) \\ & & & & \\ -0.503 & 0.264 & 0.202 & 0.796^{*} & 0.155 \\ (0.547) & (0.168) & (0.508) & (0.427) & (0.271)\end{array}$

F-test coefficients in 1st row all equal zero

Ho: No effect of 1st trimester of pregnancy

$$
F_{5,45}=1.42
$$

$p-$ value $=0.2338$

\begin{tabular}{lllll}
\hline Observations (month-year-province cells) & 13,900 & 13,900 & 13,900 & 13,900 \\
\hline \hline
\end{tabular}

Note: Live births conceived between January 1980 and February 2003.

Econometric specification: Panel A in Table 2 collapsed at the month-year-province level weighted by

the number of observations within month-year-province cell.

Standard errors clustered at the province level (50 provinces).

${ }^{* * *} p-$ value $<0.01,{ }^{* *} p-$ value $<0.05,{ }^{*} p-$ value $<0.1$ 
Table 8: Regressions of Birth Outcomes on Bomb casualties intensity indicators

\begin{tabular}{|c|c|c|c|c|c|}
\hline I. Indicators for Trimesters with High Intense Terrorism & $\begin{array}{c}\text { BW } \\
\text { (in grams) }\end{array}$ & $\begin{array}{c}\text { LBW } \\
(\text { per } 1,000)\end{array}$ & $\begin{array}{c}\text { Normal } \\
\text { (per } 1,000)\end{array}$ & $\begin{array}{c}\text { Male } \\
\text { (per } 1,000)\end{array}$ & $\begin{array}{l}\text { Premature } \\
\text { (per } 1,000)\end{array}$ \\
\hline $\mathbf{1}$ (Bomb Casualties 1st trimester of pregnancy $\geq 10$ ) & $\begin{array}{c}-9.54^{* * *} \\
(3.01)\end{array}$ & $\begin{array}{c}6.54^{* * *} \\
(0.87)\end{array}$ & $\begin{array}{c}-5.23^{* *} \\
(2.09)\end{array}$ & $\begin{array}{c}0.29 \\
(4.66)\end{array}$ & $\begin{array}{c}19.09^{* *} \\
(8.76)\end{array}$ \\
\hline $\mathbf{1}$ (Bomb Casualties 2nd trimester of pregnancy $\geq 10$ ) & $\begin{array}{l}0.283 \\
(3.71)\end{array}$ & $\begin{array}{l}-2.44 \\
(1.73)\end{array}$ & $\begin{array}{l}7.16^{* *} \\
(3.28)\end{array}$ & $\begin{array}{c}-7.69^{* * *} \\
(2.83)\end{array}$ & $\begin{array}{l}6.75^{*} \\
(3.69)\end{array}$ \\
\hline $\mathbf{1}($ Bomb Casualties 3rd trimester of pregnancy $\geq 10)$ & $\begin{array}{c}2.65 \\
(4.72)\end{array}$ & $\begin{array}{l}-2.65 \\
(2.87)\end{array}$ & $\begin{array}{l}11.16 \\
(7.90)\end{array}$ & $\begin{array}{l}-5.02 \\
(3.03)\end{array}$ & $\begin{array}{l}-5.29 \\
(6.30)\end{array}$ \\
\hline Number of live births & $6,295,035$ & $6,295,035$ & $6,607,470$ & $6,607,470$ & $6,607,470$ \\
\hline II. Indicators for Trimesters with Medium Terrorism & & & & & \\
\hline $\mathbf{1}$ (Bomb Casualties 1st trimester of pregnancy $\geq 5$ ) & $\begin{array}{c}-3.82^{* *} \\
(1.56)\end{array}$ & $\begin{array}{c}0.56 \\
(0.52)\end{array}$ & $\begin{array}{l}-6.7 \\
(4.6)\end{array}$ & $\begin{array}{l}0.78 \\
(1.2)\end{array}$ & $\begin{array}{c}7.81^{* * *} \\
(2.68)\end{array}$ \\
\hline $\mathbf{1}$ (Bomb Casualties 2nd trimester of pregnancy $\geq 5$ ) & $\begin{array}{c}-0.570 \\
(1.48)\end{array}$ & $\begin{array}{l}-1.85 \\
(1.35)\end{array}$ & $\begin{array}{c}-6.5^{* *} \\
(3.0)\end{array}$ & $\begin{array}{c}-5.4^{* *} \\
(2.2)\end{array}$ & $\begin{array}{l}-1.81 \\
(1.17)\end{array}$ \\
\hline $\mathbf{1}$ (Bomb Casualties 3rd trimester of pregnancy $\geq 5$ ) & $\begin{array}{l}0.408 \\
(2.40)\end{array}$ & $\begin{array}{c}0.43 \\
(0.74)\end{array}$ & $\begin{array}{l}0.67 \\
(1.1)\end{array}$ & $\begin{array}{c}-3.2^{* *} \\
(1.3)\end{array}$ & $\begin{array}{l}-3.15 \\
(1.94)\end{array}$ \\
\hline Number of live births & $6,295,035$ & $6,295,035$ & $6,607,470$ & $6,607,470$ & $6,607,470$ \\
\hline $\mathbf{1}$ (ETA-Bomb Casualties 1st trimester of pregnancy $\geq 1$ ) & $\begin{array}{c}0.793 \\
(0.996)\end{array}$ & $\begin{array}{l}-0.065 \\
(0.435)\end{array}$ & $\begin{array}{l}-1.71 \\
(1.03)\end{array}$ & $\begin{array}{l}-1.43 \\
(1.12)\end{array}$ & $\begin{array}{l}2.22^{* *} \\
(0.876)\end{array}$ \\
\hline $\mathbf{1}$ (ETA-Bomb Casualties 2nd trimester of pregnancy $\geq 1$ ) & $\begin{array}{c}1.36 \\
(1.64)\end{array}$ & $\begin{array}{c}-1.10 \\
(0.658)\end{array}$ & $\begin{array}{c}-2.30^{* *} \\
(1.09)\end{array}$ & $\begin{array}{l}-0.544 \\
(0.646)\end{array}$ & $\begin{array}{c}-0.69 \\
(0.872)\end{array}$ \\
\hline $\mathbf{1}$ (ETA-Bomb Casualties 3rd trimester of pregnancy $\geq 1$ ) & $\begin{array}{c}2.06 \\
(1.47)\end{array}$ & $\begin{array}{c}-0.787^{*} \\
(0.450)\end{array}$ & $\begin{array}{c}-0.279 \\
(1.30)\end{array}$ & $\begin{array}{l}-1.14 \\
(1.14)\end{array}$ & $\begin{array}{c}-2.33^{*} \\
(1.26)\end{array}$ \\
\hline Number of live births & $6,295,035$ & $6,295,035$ & $6,607,470$ & $6,607,470$ & $6,607,470$ \\
\hline
\end{tabular}

Note: Live births conceived between January 1980 and February 2003.

Econometric specification: Panel C, Table 2.

Standard errors clustered at the province level (50 provinces).

${ }^{* * *} p-$ value $<0.01,{ }^{* *} p-$ value $<0.05,{ }^{*} p-$ value $<0.1$ 
Table 9: Regressions of Birth Outcomes on Bomb Casualties by Regional Groups

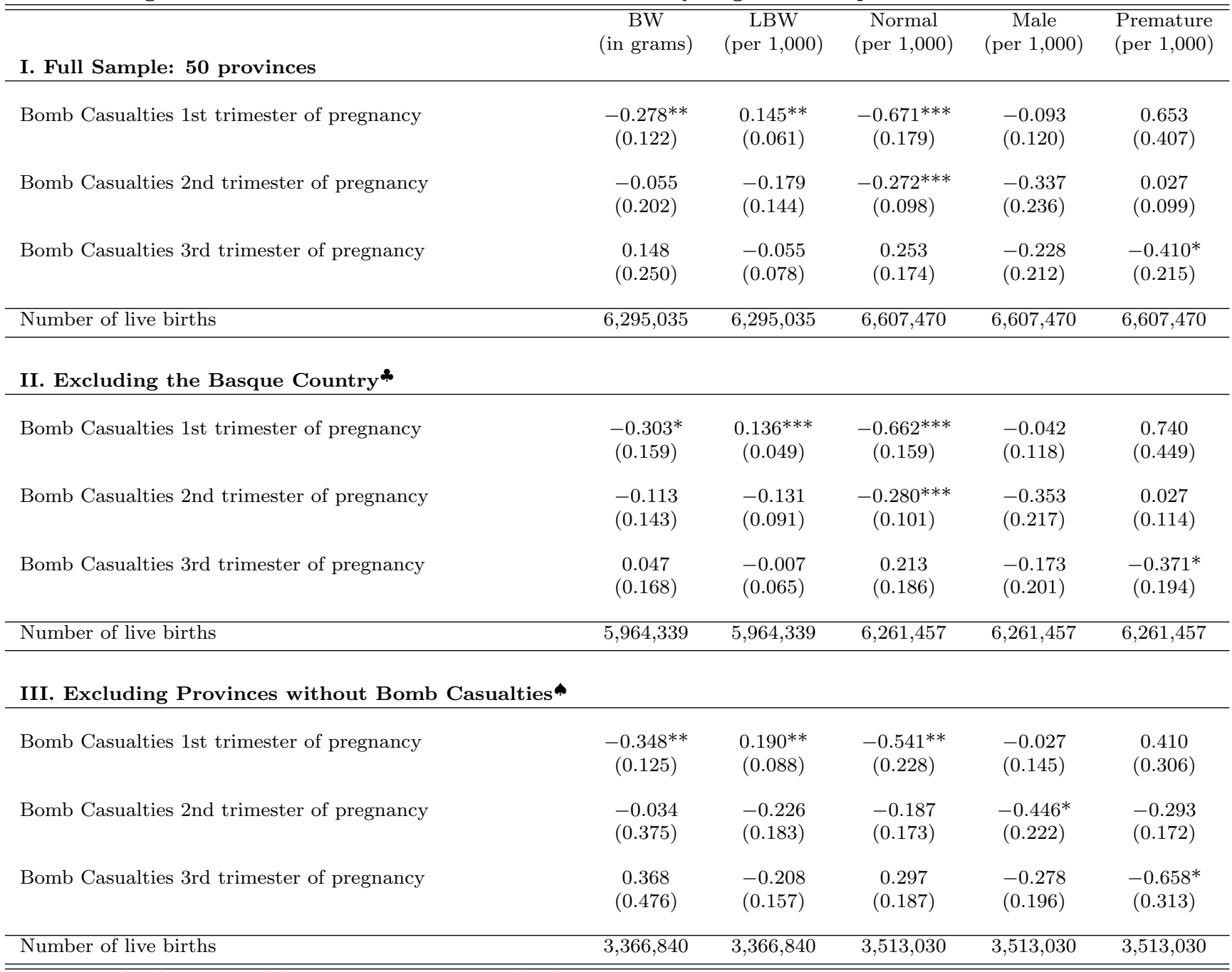

Note: Live births conceived between January 1980 and February 2003.

Econometric specification: Panel C, Table 2.

Standard errors clustered at the province level ( 47 provinces, 15 provinces).

${ }^{* * *} p-$ value $<0.01,{ }^{* *} p-$ value $<0.05,{ }^{*} p-$ value $<0.1$ 
Table 10: Regressions of Birth Outcomes on Bomb Casualties by Time Period

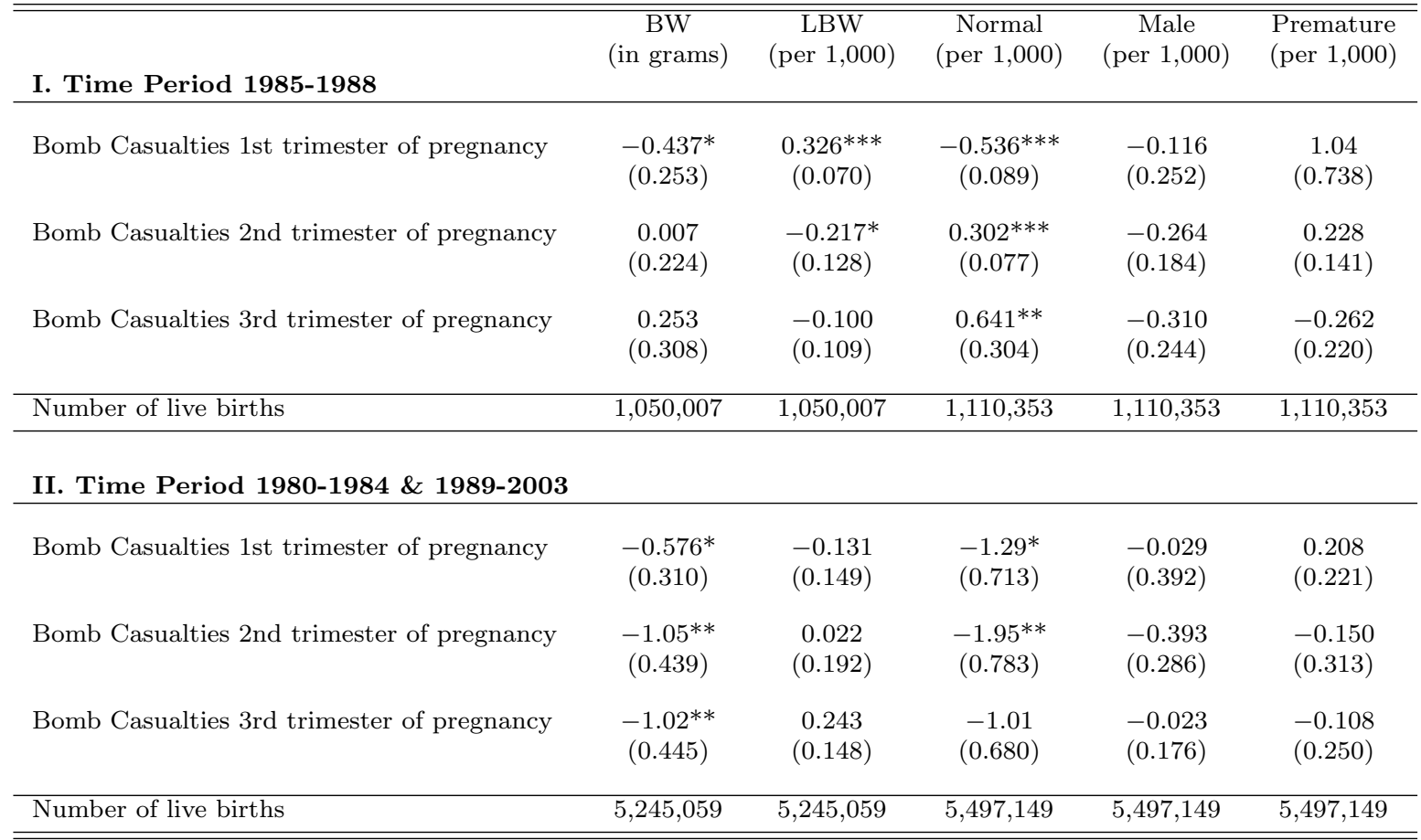

Note: Live births conceived between January 1980 and February 2003.

Standard errors clustered at the province level (50 provinces).

${ }^{* * *} p-$ value $<0.01,{ }^{* *} p-$ value $<0.05,{ }^{*} p-$ value $<0.1$ 


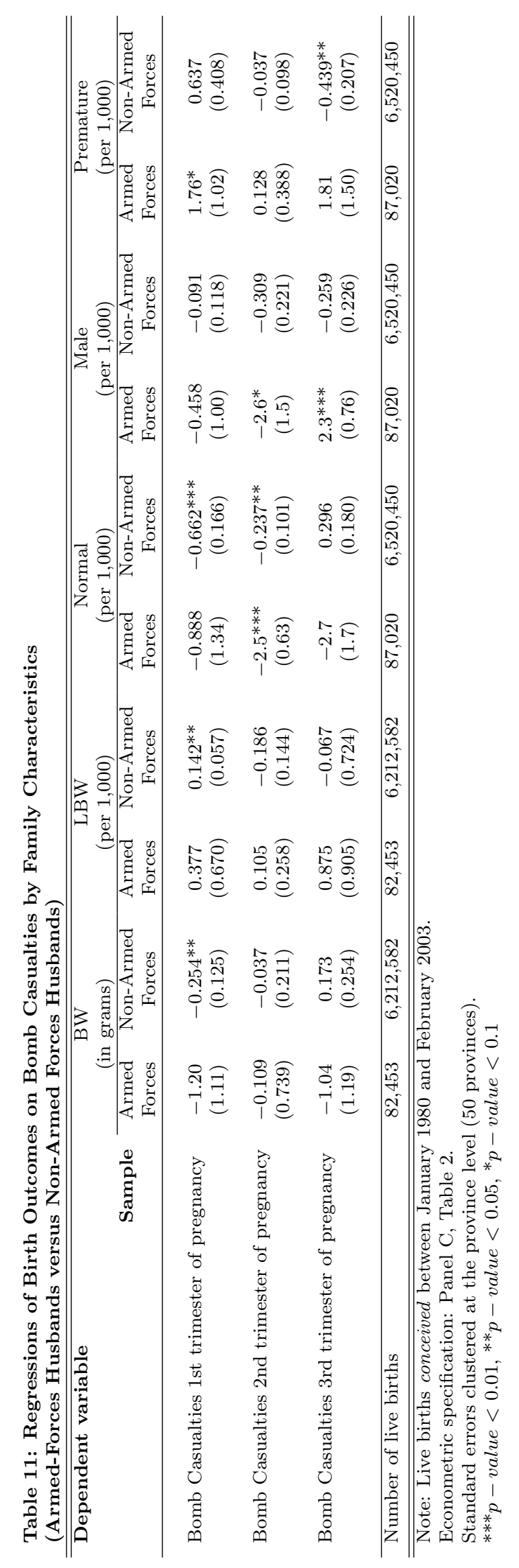


Table 12: Regressions of Population Size

\begin{tabular}{lcc}
\hline \hline & $\begin{array}{c}\text { Female population 25-54 } \\
\text { year } t \text { province } p\end{array}$ & $\begin{array}{c}\text { Male population } 25-54 \\
\text { year } t \text { province } p\end{array}$ \\
\hline Bomb casualties & -68 & 17 \\
year $t-1$ province $p$ & $(505)$ & $(554)$ \\
& & \\
Unemployment rate & $-1725^{* * *}$ & $-1882^{* * *}$ \\
year $t-1$ province $p$ & $(531)$ & $(568)$ \\
\hline Observations (year-province cells) & 1,150 & 1,150 \\
\hline Mean dependent variable & 156,343 & 156,551 \\
SD dependent variable & 198,865 & 192,413 \\
Min dependent variable & 15,625 & 17,610 \\
Max dependent variable & $1,376,268$ & $1,334,073$ \\
\hline \hline
\end{tabular}

Note: Regressions include year and province fixed effects.

Standard errors clustered at the province level (50 provinces).

${ }^{* * *} p-$ value $<0.01,{ }^{* *} p-$ value $<0.05,{ }^{*} p-$ value $<0.1$ 
Table 13: Regressions of Live births and Still births

\begin{tabular}{|c|c|c|}
\hline & Live births & Still births \\
\hline Bomb casualties trimester of conception ${ }^{b}$ & $\begin{array}{c}41.681^{* * *} \\
(13.111)\end{array}$ & - \\
\hline Bomb casualties 1st trimester of pregnancy & - & $\begin{array}{c}0.193^{* * *} \\
(0.071)\end{array}$ \\
\hline Bomb casualties 2nd trimester of pregnancy & - & $\begin{array}{c}0.096 \\
(0.084)\end{array}$ \\
\hline Bomb casualties 3rd trimester of pregnancy & - & $\begin{array}{c}0.152^{* * *} \\
(0.038)\end{array}$ \\
\hline Unemployment rate trimester of conception ${ }^{b}$ & $\begin{array}{c}-31.792^{* *} \\
(14.572)\end{array}$ & - \\
\hline Unemployment rate 1st trimester of pregnancy & - & $\begin{array}{l}-0.003 \\
(0.017)\end{array}$ \\
\hline Unemployment rate 2 nd trimester of pregnancy & - & $\begin{array}{c}-0.035^{* * *} \\
(0.012)\end{array}$ \\
\hline Unemployment rate $3 \mathrm{rd}$ trimester of pregnancy & - & $\begin{array}{c}-0.029^{*} \\
(0.017)\end{array}$ \\
\hline Observations (month-year-province cells) & 13,800 & 13,900 \\
\hline Mean dependent variable & 1,450 & 2.059 \\
\hline SD dependent variable & 1,898 & 2.932 \\
\hline Min dependent variable & 38 & 0 \\
\hline Max dependent variable & 16,683 & 25 \\
\hline
\end{tabular}

Note: Regressions include month-year and province fixed effects.

${ }^{b}$ trimester of conception is defined as the trimester before the 1st trimester of pregnancy.

Standard errors clustered at the province level (50 provinces).

${ }^{* * *} p-$ value $<0.01,{ }^{* *} p-$ value $<0.05,{ }^{*} p-$ value $<0.1$ 
Table 14: Identifying the MRTS between Terrorism and Unemployment

\begin{tabular}{|c|c|c|}
\hline & $\begin{array}{c}\mathbf{h}_{\mathbf{1}}=1-\mathrm{LBW} \\
(\text { per } 1,000)\end{array}$ & $\begin{array}{c}\mathbf{h}_{\mathbf{2}}=\text { Normal } \\
\text { (per } 1,000)\end{array}$ \\
\hline Bomb Casualties 1st trimester of pregnancy & $\begin{array}{c}-0.146^{* *} \\
(0.059)\end{array}$ & $\begin{array}{c}-0.618^{* * *} \\
(0.161)\end{array}$ \\
\hline Bomb Casualties 2nd trimester of pregnancy & $\begin{array}{c}0.181 \\
(0.139)\end{array}$ & $\begin{array}{c}-0.246^{* *} \\
(0.108)\end{array}$ \\
\hline Bomb Casualties 3rd trimester of pregnancy & $\begin{array}{c}0.055 \\
(0.076)\end{array}$ & $\begin{array}{c}0.269 \\
(0.203)\end{array}$ \\
\hline Unemployment rate 1st trimester of pregnancy & $\begin{array}{c}0.209^{* *} \\
(0.093)\end{array}$ & $\begin{array}{l}0.721^{*} \\
(0.394)\end{array}$ \\
\hline Unemployment rate 2 nd trimester of pregnancy & $\begin{array}{l}-0.138 \\
(0.110)\end{array}$ & $\begin{array}{l}0.283^{*} \\
(0.158)\end{array}$ \\
\hline Unemployment rate $3 \mathrm{rd}$ trimester of pregnancy & $\begin{array}{c}0.015 \\
(0.099)\end{array}$ & $\begin{array}{c}0.603 \\
(0.566)\end{array}$ \\
\hline Ratio of Coefficients & $\begin{array}{c}-0.697^{* *} \\
(0.336)\end{array}$ & $\begin{array}{c}-0.857^{* *} \\
(0.425)\end{array}$ \\
\hline Adjusted Wald Test & \multicolumn{2}{|c|}{$\begin{array}{c}F_{1,49}=0.07 \\
p-\text { value }=0.7933\end{array}$} \\
\hline Number of live births & \multicolumn{2}{|c|}{$6,607,470$} \\
\hline
\end{tabular}

Note: Live births conceived between January 1980 and February 2003.

Simultaneous estimation accounting for clustering.

Econometric specification: Panel C, Table 2.

${ }^{* * *} p-$ value $<0.01,{ }^{* *} p-$ value $<0.05,{ }^{*} p-$ value $<0.1$ 
Figure 1: Quarterly Evolution of ETA casualties: 1980-2003

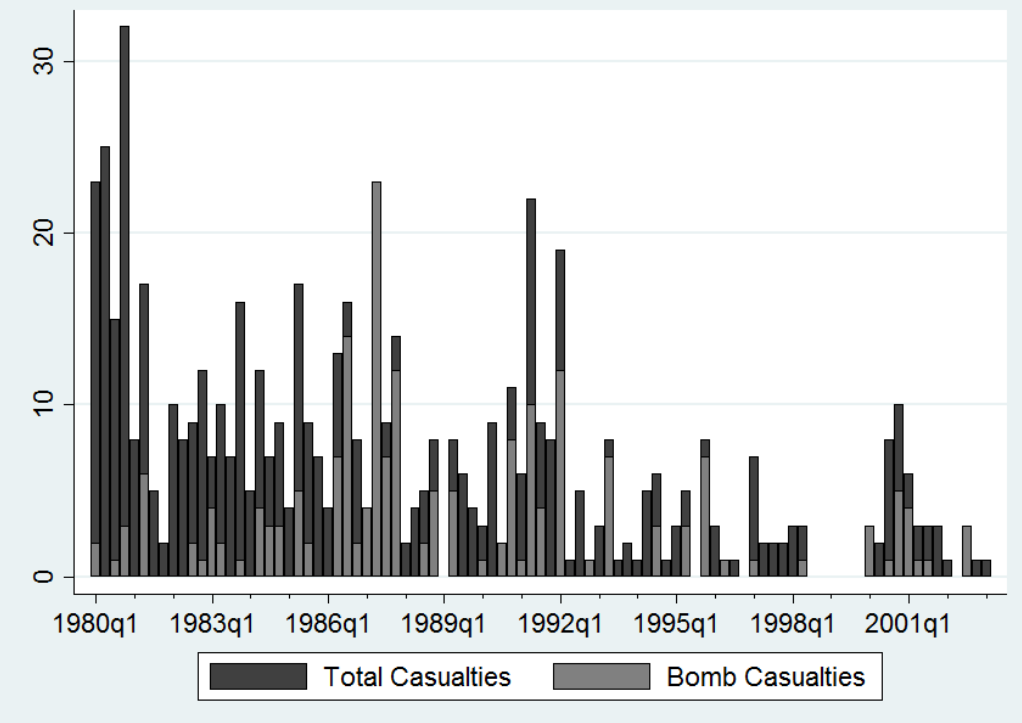


Figure 2: Bomb Casualties by province: 1980-2003

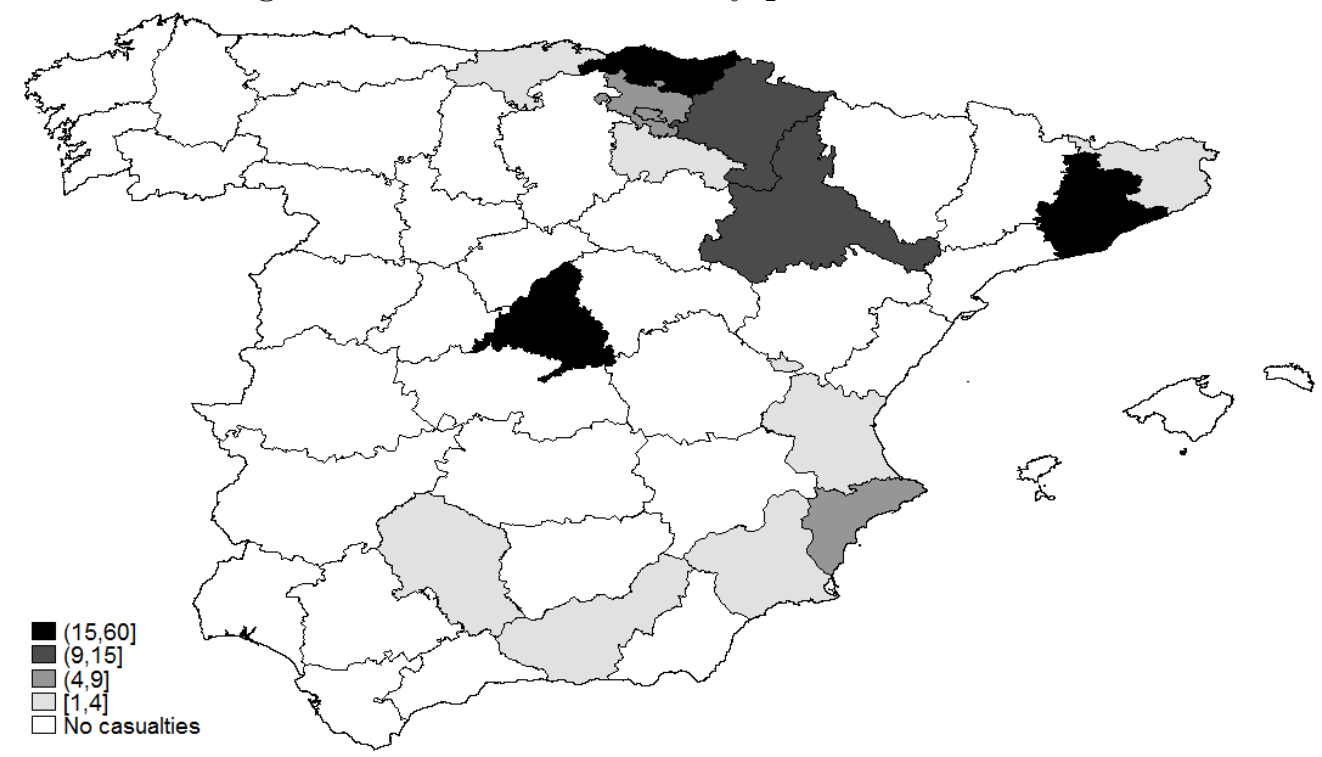

Figure 3: Total Casualties by province: 1980-2003

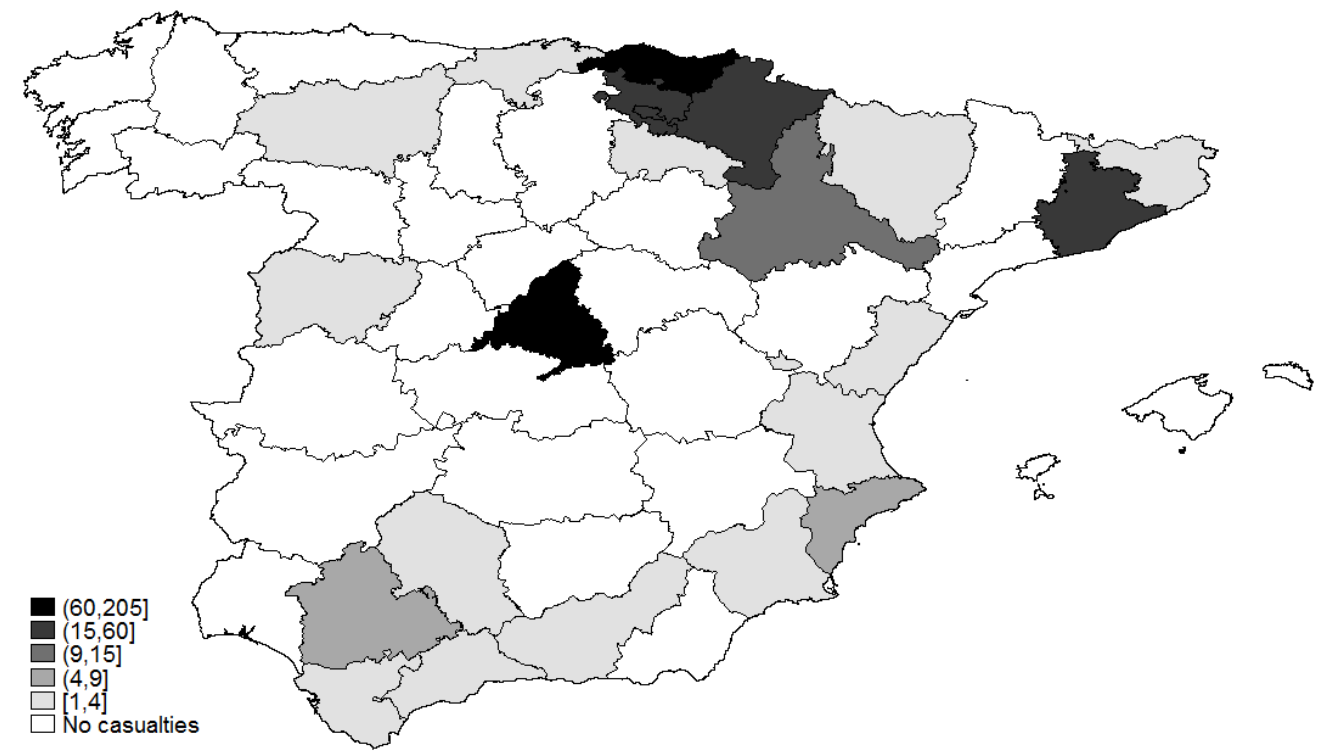


Normality and Bomb Casualties in the 1st trimester of pregnancy

Figure 4: Full sample

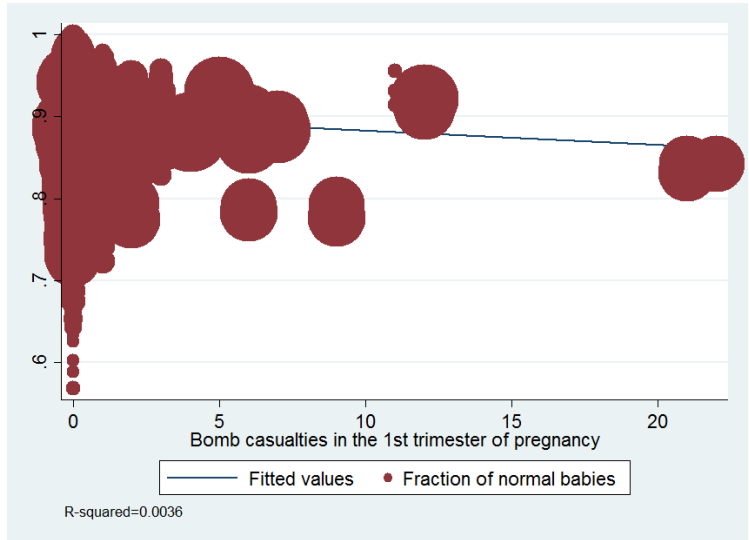

Figure 6: at least 5 casualties

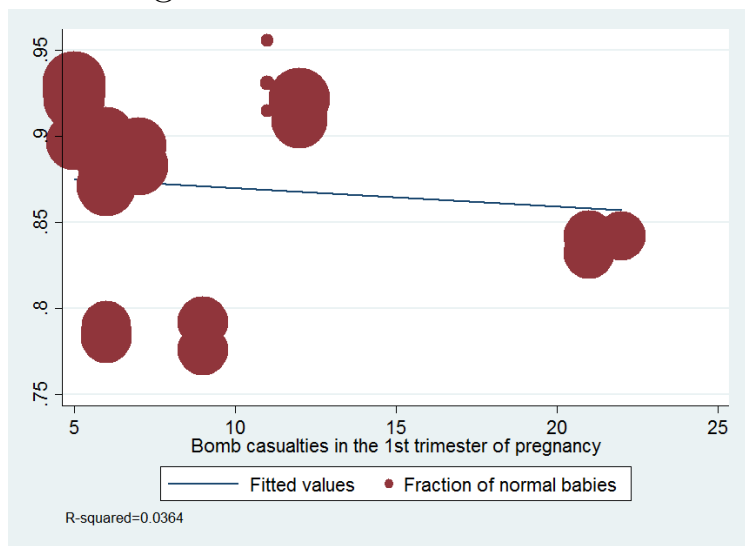

Figure 5: at least one casualty

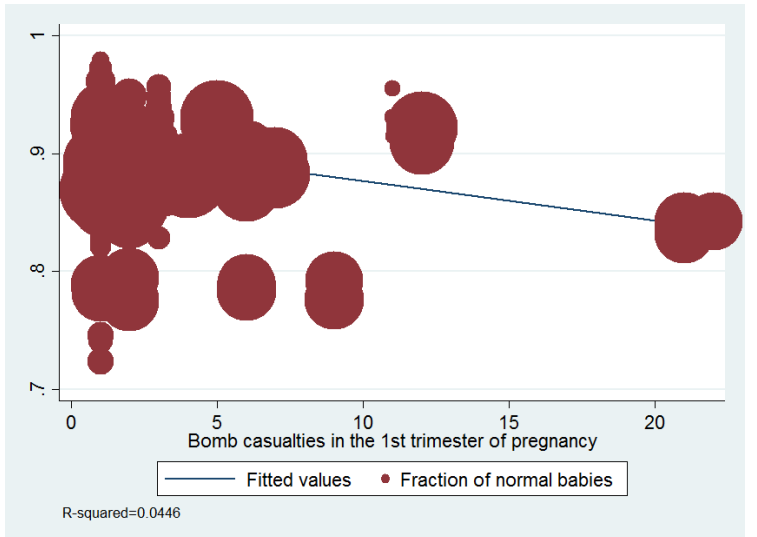

Figure 7: at least 10 casualties

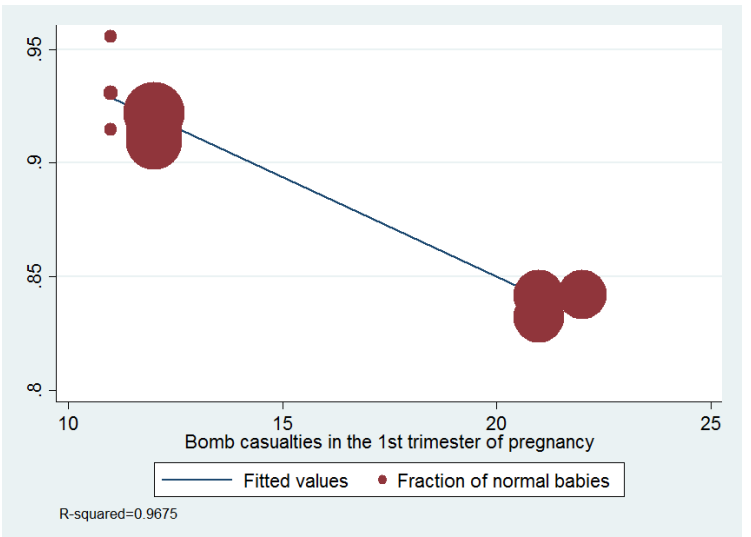

Note: Data collapsed at the month-year-province level (and weighted by the number observations within each cell). 


\section{Appendix}

Table A1: Regressions of Birth Outcomes on All casualties (prenatal exposure measured counting forward from estimated conception date)

\begin{tabular}{lccccc}
\hline \hline & $\begin{array}{c}\text { BW } \\
\text { A. Year-Month FE \& Province FE }\end{array}$ & $\begin{array}{c}\text { LBW } \\
\text { (per 1,000) }\end{array}$ & $\begin{array}{c}\text { Normal } \\
(\text { per 1,000) }\end{array}$ & $\begin{array}{c}\text { Male } \\
(\text { per 1,000) }\end{array}$ & $\begin{array}{c}\text { Premature } \\
(\text { per 1,000) }\end{array}$ \\
\hline All Casualties 1st trimester of pregnancy & $\begin{array}{c}-0.908^{* *} \\
(0.460)\end{array}$ & $\begin{array}{c}0.294^{*} \\
(0.158)\end{array}$ & $\begin{array}{c}-1.01^{* * *} \\
(0.333)\end{array}$ & $\begin{array}{c}-0.035 \\
(0.162)\end{array}$ & $\begin{array}{c}0.914^{* *} \\
(0.405)\end{array}$ \\
All Casualties 2nd trimester of pregnancy & -0.679 & -0.066 & $-0.795^{* *}$ & -0.315 & $0.301^{*}$ \\
& $(0.552)$ & $(0.156)$ & $(0.355)$ & $(0.195)$ & $(0.181)$ \\
All Casualties 3rd trimester of pregnancy & -0.383 & 0.065 & -0.376 & 0.260 \\
& $(0.550)$ & $(0.143)$ & $(0.486)$ & $(0.219)$ & $(0.118$ \\
& & & & $6,257)$ \\
\hline Number of live births & $6,327,753$ & $6,327,753$ & $6,641,478$ & $6,641,478$ & $6,641,478$ \\
\hline
\end{tabular}

\section{B. (A) \& Socio-Demographic Controls}

\begin{tabular}{|c|c|c|c|c|c|}
\hline All Casualties 1st trimester of pregnancy & $\begin{array}{c}-1.01^{* *} \\
(0.456)\end{array}$ & $\begin{array}{c}0.336^{* *} \\
(0.165)\end{array}$ & $\begin{array}{c}-1.02^{* * *} \\
(0.365)\end{array}$ & $\begin{array}{l}-0.030 \\
(0.164)\end{array}$ & $\begin{array}{c}0.899 * * \\
(0.393)\end{array}$ \\
\hline All Casualties 2nd trimester of pregnancy & $\begin{array}{l}-0.671 \\
(0.530)\end{array}$ & $\begin{array}{l}-0.057 \\
(0.165)\end{array}$ & $\begin{array}{c}-0.713^{* *} \\
(0.348)\end{array}$ & $\begin{array}{l}-0.311 \\
(0.196)\end{array}$ & $\begin{array}{c}0.269 \\
(0.175)\end{array}$ \\
\hline All Casualties 3rd trimester of pregnancy & $\begin{array}{c}-0.409 \\
(0.518)\end{array}$ & $\begin{array}{c}0.088 \\
(0.141)\end{array}$ & $\begin{array}{c}-0.278 \\
(0.467)\end{array}$ & $\begin{array}{c}-0.256 \\
(0.219)\end{array}$ & $\begin{array}{c}0.091 \\
(0.250)\end{array}$ \\
\hline
\end{tabular}

\begin{tabular}{llllll}
\hline Number of live births & $6,295,035$ & $6,295,035$ & $6,607,470$ & $6,607,470$ & $6,607,470$ \\
\hline
\end{tabular}

Note: Live births conceived between January 1980 and February 2003.

Standard errors clustered at the province level (50 provinces).

${ }^{* * *} p-$ value $<0.01,{ }^{* *} p-$ value $<0.05,{ }^{*} p-$ value $<0.1$ 